\title{
Hydroxide Complexes of the Late Transition Metals: Organometallic Chemistry and Catalysis
}

David J. Nelson ${ }^{\mathrm{a}}$ and Steven P. Nolan ${ }^{\mathrm{b}}$

a) WestCHEM Department of Pure and Applied Chemistry, University of Strathclyde, 295 Cathedral Street, Glasgow, G1 1XL, UK. david.nelson@strath.ac.uk

b) Department of Chemistry and Center for Sustainable Chemistry, Ghent University, Campus Sterre, Building S3, Krijgslaan 281, 9000 Ghent, Belgium. steven.nolan@ugent.be

\begin{abstract}
Transition metal hydroxides of the late transition metals are now relatively common, and play a special role in both the synthesis of new complexes and in important catalytic reactions. The basic nature of this ligand lends these complexes to transmetallation and deprotonation reactions, while small molecules such as $\mathrm{CO}_{2}$ can insert into the metal-oxygen bond. This review analyses and discusses the progress of this field over approximately the past decade.
\end{abstract}

\section{Contents}

- Introduction

- Group 8: Iron, Ruthenium, and Osmium

- Group 9: Cobalt, Rhodium, and Iridium

- Group 10: Nickel, Palladium, and Platinum

- Group 11: Copper, Silver, and Gold

- Summary

\section{Introduction}

Transition metal complexes of groups $8-11$ have a variety of interesting and useful roles in organometallic chemistry and catalysis. Amongst these species, transition metal hydroxide complexes have found application in catalysis and small molecule activation. Spectroscopic studies of pincersupported nickel and palladium complexes have allowed the quantification of the electron donating properties of a range of anionic ligands, including hydroxide, ${ }^{1}$ showing that hydroxide is somewhat similar to bromide and chloride in this respect, but less electron donating than iodide or amide. However, the range of reactivity that is observed from this simple anionic ligand is varied and exciting. In addition, they have been implicated in reactions such as Suzuki-Miyaura cross-coupling reactions, where a palladium or nickel hydroxide complex is formed in situ and transmetalates more rapidly with a boronic acid than a metal halide complex transmetalates with a boronate. ${ }^{2,3}$ 
The most common methods by which these species are prepared are (i) halide replacement using a metal hydroxide salt and (ii) the reaction of a complex with a highly basic ligand, such as $\mathrm{N}\left(\mathrm{SiMe}_{3}\right)_{2}$, with water. Late transition metal hydroxide complexes tend to exhibit several common reactivity patterns. Firstly, the relatively basic hydroxide ligand $\left(\mathrm{pK}_{\mathrm{a}} \text { of } \mathrm{H}_{2} \mathrm{O} \text { in DMSO }=33\right)^{4}$ can deprotonate many reagents with relatively acidic $\mathrm{C}-\mathrm{H}$ bonds, such as alcohols, acetylenes, fluoroarenes, and so forth. Metal hydroxide complexes are often used as starting materials for the preparation of silyloxide complexes. ${ }^{5}$ Secondly, it is often possible to achieve insertion of molecules such as $\mathrm{CO}_{2}$ into the metal-oxygen bond. Thirdly, transmetallation from, for example, boronic acids is often a robust and general way to use hydroxide complexes for the generation of new organometallic complexes.

This Review covers much of the progress in this field over the past decade or so; Roesky and co-workers published a detailed review in $2006,{ }^{6}$ and so this manuscript considers the primary literature since then. We will consider the synthesis, properties, and reactions of each transition metal hydroxide complex, with a particular focus on their relevance to or promise in homogenous catalysis.

\section{Group 8: Iron, Ruthenium, and Osmium}

Iron

There are relatively few known well-defined iron hydroxide complexes, and all are prepared using methods that involve the presence of water. The complexes are most often polynuclear species with bridging hydroxyl ligands, and are typically prepared by the reaction of iron complexes with water. $\left[\mathrm{Fe}\left(\mathrm{Cp}^{\prime}\right)\left(\mathrm{N}\left(\mathrm{SiMe}_{3}\right)_{2}\right)\right]$ reacts with degassed water, in $\left(\mathrm{Me}_{3} \mathrm{Si}\right)_{2} \mathrm{O}$, to form the trinuclear complex $\left[\mathrm{Fe}\left(\mathrm{C} p^{\prime}\right)(\mu-\mathrm{OH})\right]_{3}(\mathbf{1})\left(C p^{\prime}=1,2,4\right.$-tri(tert-butyl)cyclopentadienyl) (Scheme $\left.1(\mathrm{a})\right) .^{7}$ The product is a high spin Fe" complex $(S=2)$ that shows antiferromagnetic coupling between the metal centres. $\mathbf{1}$ is thermally unstable and decomposes by transfer of a $\mathrm{H}$ from the hydroxide ligand to a $\mathrm{Cp}^{\prime}$ ligand. The analogous complex $\left[\mathrm{Fe}\left({ }^{5} \mathrm{Cp}\right)\left(\mathrm{N}\left(\mathrm{SiMe}_{3}\right)_{2}\right)\right]$ reacts with water in THF to form a hydroxide-bridged dimer $\left[\mathrm{Fe}\left({ }^{5} \mathrm{Cp}\right)(\mu-\mathrm{OH})\right]_{2}(2)\left({ }^{5} \mathrm{Cp}=1,2,3,4,5-\right.$ penta(isopropyl)cyclopentadienyl) (Scheme 1 (b)). ${ }^{8}$ The reaction of $\mathrm{Fe}_{3}(\mathrm{CO})_{12}$ with $\mathrm{Ph}_{2} \mathrm{PH}$ and $\mathrm{Et}_{3} \mathrm{~N}$ led to a mixture of complexes of the form $\left[\mathrm{Fe}_{2}(\mathrm{CO})_{6}(\mu-\mathrm{X})\left(\mu-\mathrm{PPh}_{2}\right)\right]$, where $\mathrm{X}=\mathrm{OH}(3), \mathrm{PPh}_{2}$, or $\mathrm{OPPh}_{2}$ ) (Scheme 1 (c)). It was proposed that the oxygen atom was obtained from adventitious air in the THF solvent; the addition of water led to an increased yield of the hydroxide complex. ${ }^{9}$ Complexes based on tris(pyrazolyl)borate and pyridinediimine ligands have been prepared in a similar way (Scheme $1(\mathrm{~d}),(\mathrm{e})) .{ }^{10}$ 
(a)

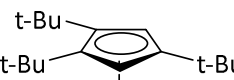

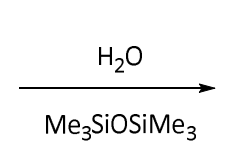

$\mathrm{t}-\mathrm{Bu}$

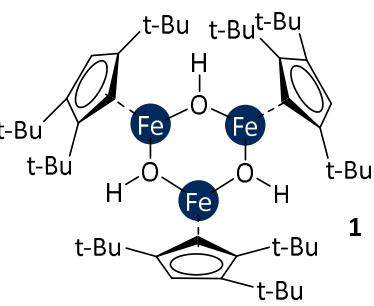

(b)
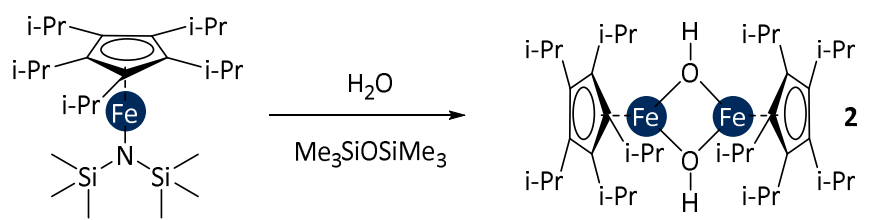

(c) $\mathrm{Ph}_{2} \mathrm{PH} \underset{\mathrm{NEt}_{34} \mathrm{THF}}{\stackrel{\mathrm{Fe}_{3}(\mathrm{CO})_{12}}{\longrightarrow}} \mathrm{OC}$

(d)
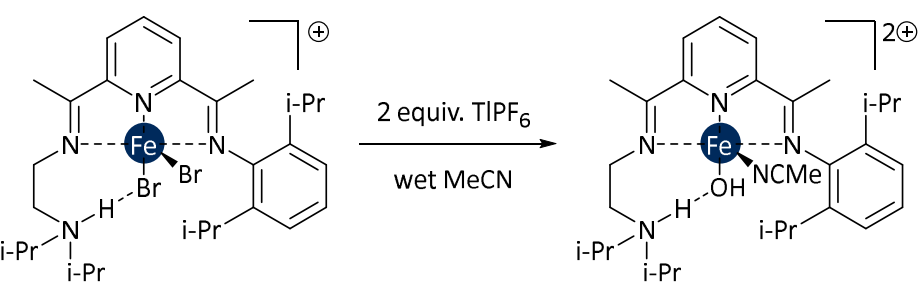

(e)
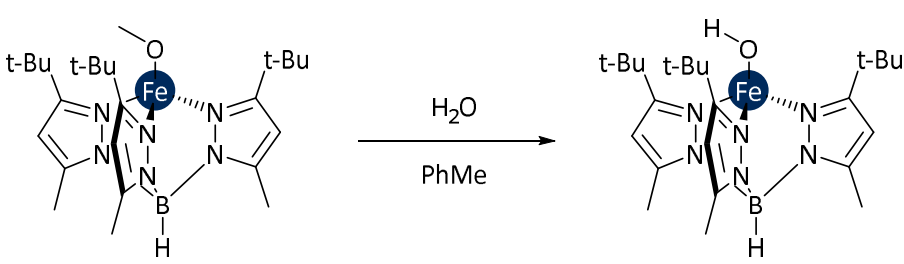

Scheme 1. Synthesis of iron hydroxide complexes.

Iron(II) hydroxide complexes have been implicated as intermediates in ketone hydrosilylation. ${ }^{11}$ An iron(II) complex with a Cp-tethered NHC underwent reaction with potassium tert-butoxide to form an unstable alkoxide complex (Scheme 2); this in turn reacted with water present in the THF solvent to form a compound consistent with hydroxide species 4. The putative hydroxide complex was also prepared by reaction of $\mathbf{5}$ with potassium hydroxide in THF. Unfortunately, a clean sample could not be obtained for full characterisation, so the monomeric nature of this species cannot be confirmed. Interestingly, 5, which is inactive for hydrosilylation, does not undergo ligand exchange with $\mathrm{KO}^{t} \mathrm{Bu}$.

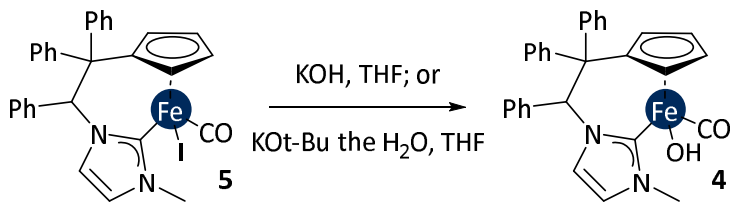

Scheme 2. Proposed hydroxide intermediate in iron-catalysed hydrosilylation. 


\section{Ruthenium}

Ruthenium hydroxide complexes have been applied in a number of stoichiometric studies and in various catalytic applications. For example, Yi has applied a ruthenium cluster $\left[\left(\mathrm{PC} \mathrm{y}_{3}\right)(\mathrm{CO}) \mathrm{RuH}\right]_{4}\left(\mu_{4^{-}}\right.$ $\mathrm{O})\left(\mu_{3}-\mathrm{OH}\right)\left(\mu_{2}-\mathrm{OH}\right)$ in catalytic applications such as alcohol oxidation and dehydrogenation. ${ }^{12,}{ }^{13}$ $\left[\left(\mathrm{Ru}\left(\mathrm{PMe}_{3}\right)_{3}\right)_{2}(\mu-\mathrm{OH})_{3}\right]^{+}$has been employed in $E$-selective alkyne dimerization reactions ${ }^{14}$ and in nitrile hydration. ${ }^{15}$ Ruthenium hydroxide intermediates have been implicated in other nitrile hydration reactions, ${ }^{16}$ and in the dehydrogenation of methanol. ${ }^{17}$

Several dimeric ruthenium complexes with bridging hydroxide ligands were prepared from the reaction of the corresponding chloride complexes with aqueous base, and were applied in the reduction of alkynes using alcohols as the hydrogen source (Scheme 3$) \cdot{ }^{18}$ Stoichiometric reactions of these hydroxide species with chloroform led to the corresponding chloride complexes, presumably due to reaction with traces of $\mathrm{HCl}$ present, while reaction with alcohols or $\mathrm{LiBHEt}_{3}$ led to the formation of ruthenium hydride species.

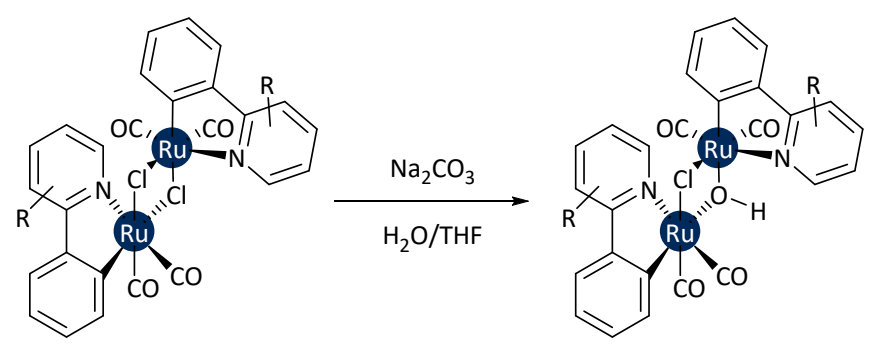

Scheme 3. Synthesis of dimeric ruthenium complexes with bridging hydroxide ligands.

Ligand exchange processes in $\left[\mathrm{Ru}(\mathrm{L})(\mathrm{NCMe})_{4}\left(\mathrm{Pi}_{-} \mathrm{Pr}_{3}\right)\right]^{2+}$ complexes have been studied. ${ }^{19}$ $\left[\mathrm{Ru}(\mathrm{NCMe})_{4}\left(\mathrm{OH}_{2}\right)\left(\mathrm{Pi}_{-}-\mathrm{Pr}_{3}\right)\right]^{2+}$ was formed from the reaction of water with $\left[\mathrm{RuCl}(\mathrm{NCMe})_{4}\left(\mathrm{Pi}_{-}-\mathrm{Pr}_{3}\right)\right]^{+}$. The hydroxide ligand could be deprotonated using aqueous potassium hydroxide in dichloromethane solution. The $\mathrm{pK}_{\mathrm{a}}$ of the hydroxide ligand was measured by ${ }^{31} \mathrm{P}$ NMR spectroscopy in solutions of different $\mathrm{pH}$ and was found to be 10.5 .

Ruthenium and osmium hydride complexes that react with one equivalent of water to form hydridohydroxide species. ${ }^{20}$ The ligand also participates in these reactions, and becomes protonated (Scheme 4). In the solid state, the ruthenium complex exhibits hydrogen bonding to water in the unit cell, with two hydroxide molecules each hydrogen bonding to the same pair of water molecules. The addition of an extra equivalent of water leads to hydrogen bonding between the water and the hydroxide and $\mathrm{NH}_{2}$ groups. 


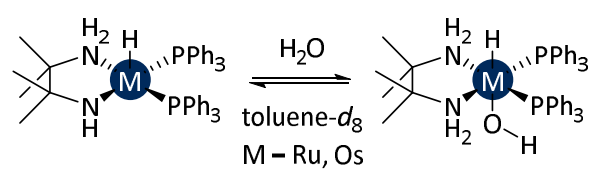

Scheme 4. Reaction of ruthenium and osmium hydride complexes with water.

Half-sandwich ruthenium hydroxide complexes $\mathbf{6 a}$ and $\mathbf{6 b}$ bearing NHCs have been prepared by salt metathesis and been shown to be capable of catalysing the racemisation of chiral secondary alcohols (Scheme 5). ${ }^{21}$ The synthetic route is straightforward and the compounds were fully characterised; X-ray crystal structures confirmed their monomeric structure. However, these species are not as active as the alternative $[\mathrm{RuCl}(\mathrm{Cp})(\mathrm{NHC})] / \mathrm{KOt}$-Bu catalytic system, which are proposed to generate an active $\left[\mathrm{Ru}\left(\mathrm{Cp}^{*}\right)(\mathrm{Ot}-\mathrm{Bu})(\mathrm{NHC})\right]$ catalyst in situ. ${ }^{22}$

(a)
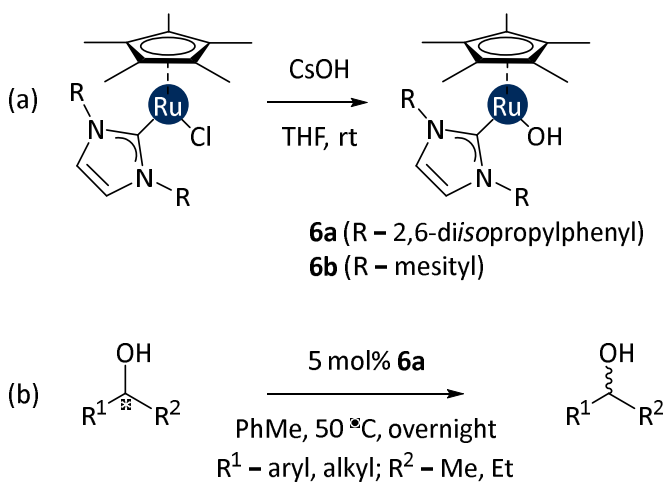

Scheme 5. Ruthenium hydroxide complexes as catalysts for alcohol racemisation.

\section{Osmium}

A number of osmium hydroxide complexes have been reported, in addition to the species studied by Morris, ${ }^{20}$ and appear to be rather more common than their ruthenium and iron analogues.

Tp-supported osmium dihydroxide complexes were prepared from the reaction of the corresponding acetate complex with sodium hydroxide, and characterised by X-ray crystal diffraction analysis (Scheme 6). ${ }^{23}$ Experiments with $\mathrm{D}_{2} \mathrm{O}$ led to rapid exchange of the proton, while the use of $\mathrm{Na}{ }^{18} \mathrm{OH}$ confirmed that reaction took place via displacement of the acetate ligands rather than via hydrolysis of the acetate ligands; i.e. there is formation of a new Os-O bond and the release of acetate, rather than nucleophilic attack at the acetate carbonyl moiety by water. 


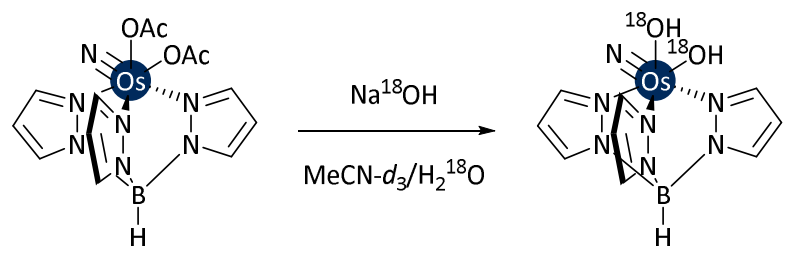

Scheme 6. Osmium hydroxide complexes.

A series of arene-bearing osmium hydroxide complexes have been evaluated for use as anticancer agents. These were formed from the in situ hydrolysis and deprotonation of the corresponding chloride complexes (Scheme 7). ${ }^{24}$ Values for $\mathrm{pK}_{\mathrm{a}}{ }^{*}$ were found to be $7.3-7.8$.

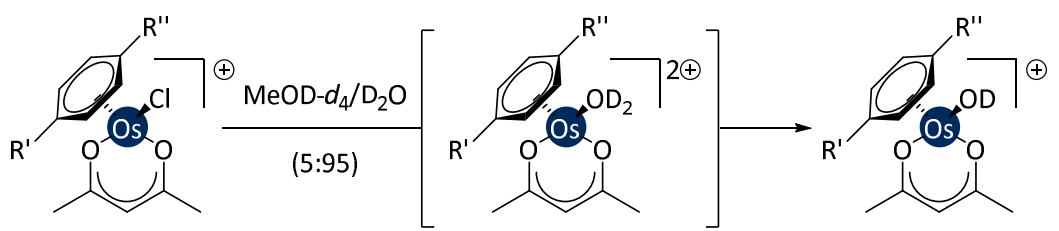

Scheme 7. (Arene)osmium hydroxide complexes $\left(R^{\prime}, R^{\prime \prime}=H ; R^{\prime}=M e, R^{\prime}=i-P r ; R^{\prime}=P h, R^{\prime \prime}=H\right)$.

Shapley has prepared a series of $\left[\mathrm{Os}(\mathrm{N})\left(\mathrm{CH}_{2} \mathrm{SiMe}_{3}\right)_{n}(\mathrm{OH})_{4-\mathrm{n}}\right]^{-}$complexes. ${ }^{25}$ These could be prepared in two ways. The first involved protonation of one of the $\mathrm{TMSCH}_{2}$ ligands with a pyridinium reagent, leading to a pyridine complex which reacted with a soluble source of hydroxide (Scheme 8 (a)). The second route proceeded via a salt metathesis route, in which one of the chloride ligands was replaced with hydroxide using sodium hydroxide (Scheme 8 (b)).

(a)

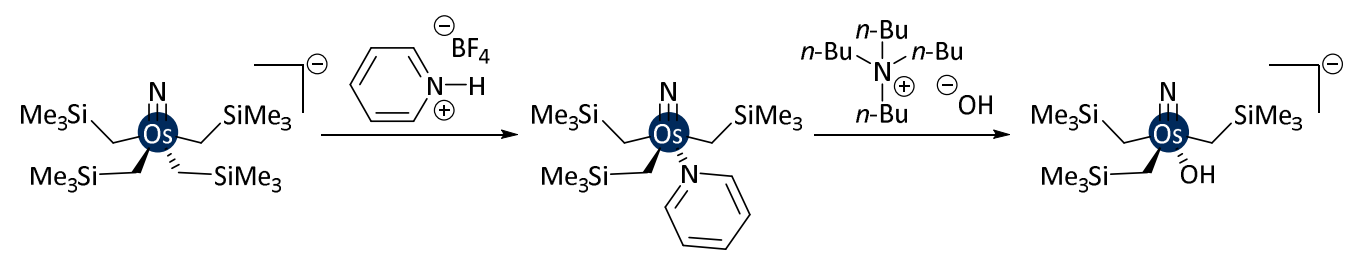

(b)

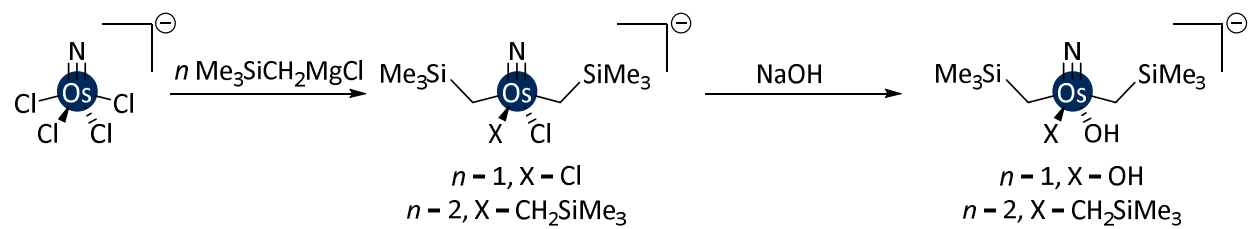

Scheme 8. Synthetic routes to (alkyl)osmium hydroxide complexes.

NHC-bearing Os(II) complex 7 was prepared by salt metathesis from the corresponding chloride complex, and its diverse reactivity was studied extensively (Scheme 9). ${ }^{26}$ The hydroxide species could be converted to the dihydride complex by reaction with sodium borohydride and 
methanol, or to the trihydride complex by reaction with hydrogen. 7 was shown to be active in transfer hydrogenation reactions; the basic hydroxide ligand was capable of deprotonating alcohols to form alkoxide complexes, of which some examples have been isolated and characterised. In the case of isopropanol, spontaneous $\beta$-hydride elimination occurs to form a hydride complex with acetone coordinated. 7 has also been applied to the alkylation of arylacetonitriles and methyl ketones, ${ }^{27}$ and the hydration of nitriles to amides. ${ }^{28} 7$ also undergoes insertion reactions with aldehydes to yield carboxylate complexes. ${ }^{29}$

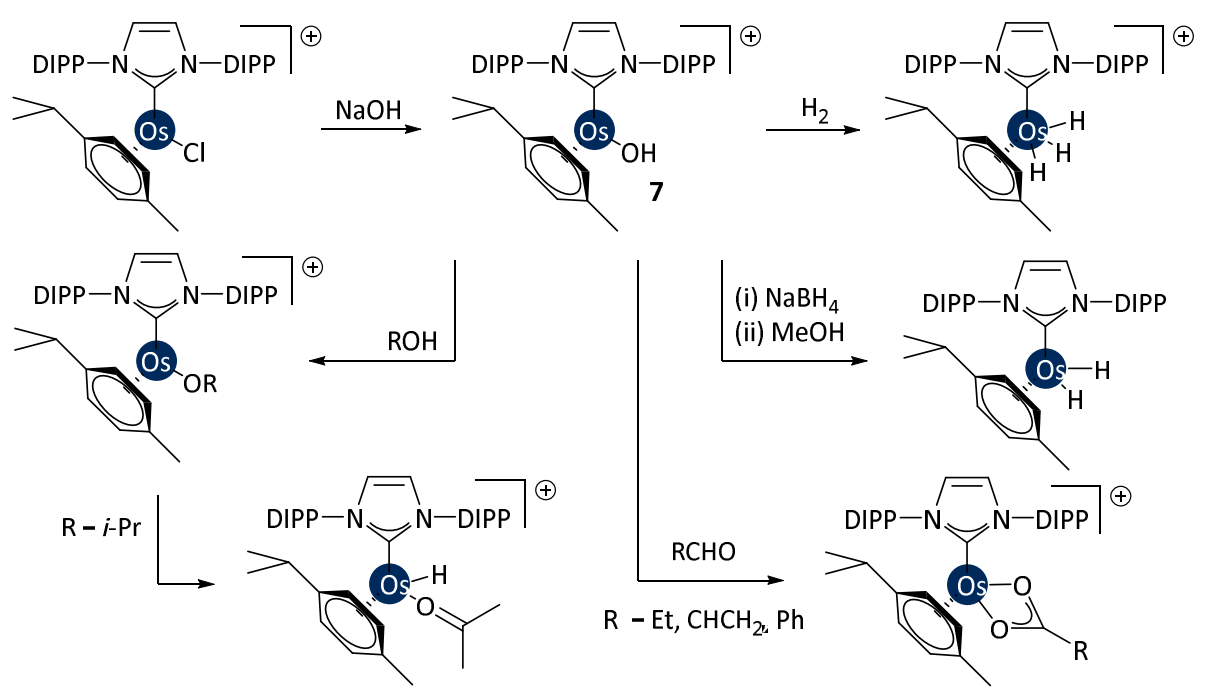

Scheme 9. Formation and reactions of an NHC-osmium hydroxide complex (DIPP $=2,6$ diisopropylphenyl).

A trinuclear (dppf)osmium(carbonyl) complex with bridging hydroxide ligands has been reported to result from the reaction of a complex with two bridging hydrides with triphenyl tin, in the presence of dppf, albeit in low yield (8\%) as a component of a complex mixture of products. ${ }^{30}$

\section{Group 11: Cobalt, Rhodium, and Iridium}

\section{Cobalt}

Relatively few cobalt hydroxide species have been reported in the past decade. Complex $\mathbf{8}$ is one example, and was prepared by reacting $\mathrm{CoF}_{3}$ and $\mathrm{CoCl}_{2}$ with an aminotriazole ligand and $\mathrm{KCN}$ in aqueous solution (Scheme 10). ${ }^{31}$ This species was studied by XANES, XES, and DFT to reveal differences in the electronic structure of the $\mathrm{Co}^{\prime \prime \prime}$ and $\mathrm{Co}^{\prime \prime}$ centres. The terminal cobalt centres are in the +3 oxidation state, while the central cobalt atom was found to be in the +2 oxidation state. 

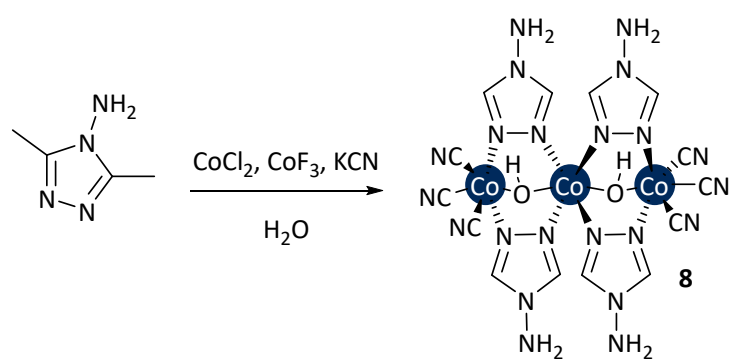

Scheme 10. Synthesis of a Co"/Co"l complex with bridging hydroxide ligands. ${ }^{31}$

\section{Rhodium}

A number of rhodium hydroxide complexes have been prepared, and have been deployed in synthesis. Simple hydroxide complexes such as $[\mathrm{Rh}(\mu-\mathrm{OH})(\mathrm{COD})]_{2}$ have been known for some time, ${ }^{32}$ but a number of groups have recently exploited more elaborate complexes in catalytic reactions. The bond strengths of various Rh-O bonds in $\left[\mathrm{RhH}(\mathrm{OR})\left(\mathrm{PMe}_{3}\right)\left(\mathrm{Tp}^{\prime}\right)\right]$ have been estimated by experimental means; the Rh-O bond in $\left[\mathrm{RhH}(\mathrm{OH})\left(\mathrm{PMe}_{3}\right)\left(\mathrm{Tp}^{\prime}\right)\right]$ is stronger (by ca. $8-17 \mathrm{kcal} \mathrm{mol}^{-1}$ ) than those in various alkoxide analogues $\left(\mathrm{Tp}^{\prime}=\operatorname{tris}\left(3,5\right.\right.$-dimethylpyrazolyl)borate) ${ }^{33}$

Several other $N$-heterocycles have been used as supporting ligands for rhodium hydroxide complexes. $\left[\mathrm{Rh}(\mathrm{OH})_{2}\left({ }^{t} \mathrm{bpy}\right)_{2}\right] \mathrm{OTf}$ was prepared by reaction of the bis(triflate) complex with excess $\mathrm{CsOH}$, while $\left[\mathrm{Rh}(\mathrm{OH})_{2}(\mathrm{bpy})_{2}\right] \mathrm{PF}_{6}$ was prepared in the same manner from $\left[\mathrm{RhCl}(\mathrm{py})(\mathrm{bpy})_{2}\right]\left[\mathrm{PF}_{6}\right]_{2}\left({ }^{\mathrm{t}} \mathrm{bpy}=\right.$ 4,4'-di(tert-butyl)-2,2'-bypyridine; bpy $=2,2^{\prime}$-bipyridine). ${ }^{34}\left[\mathrm{Rh}(\mathrm{OH})\left(\mathrm{OH}_{2}\right)_{2}\right.$ (terpy) $]\left[\mathrm{NO}_{3}\right]_{2}$ was prepared by the reaction of $\left[\mathrm{RhCl}_{3}(\right.$ terpy) $]$ with aqueous silver nitrate (terpy $=$ terpyridine). ${ }^{35}$

Rhodium hydroxide complexes have been used for the catalytic hydrothiolation of alkynes. ${ }^{36}$ The dimeric complex $[\mathrm{Rh}(\mu-\mathrm{OH})(\mathrm{COE})(\mathrm{NHC})]_{2}$ (9) was prepared by salt metathesis from $[\mathrm{Rh}(\mu-$ $\mathrm{Cl})(\mathrm{COE})(\mathrm{NHC})]_{2}$, and was converted to $[\mathrm{Rh}(\mu-\mathrm{OH})(\mathrm{HCCH})(\mathrm{NHC})]_{2}(\mathbf{1 0})$ by reaction with acetylene (Scheme 11 (a)). Both hydroxide complexes were active in hydrothiolation, but the addition of pyridine had a significant beneficial effect on both conversion and selectivity ( $\alpha$ vs $\beta$ ). A series of sulfide intermediates could be prepared by reaction of 9 with benzyl sulfide (Scheme 11 (b)). 
(a)

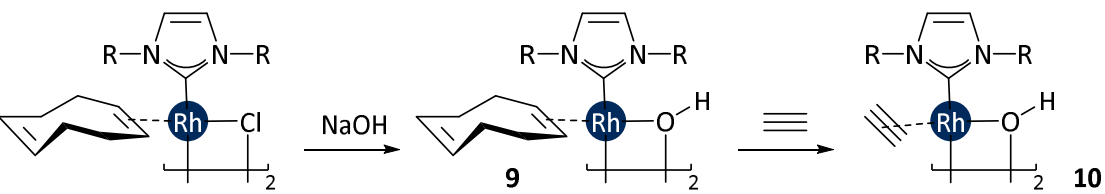

(b)

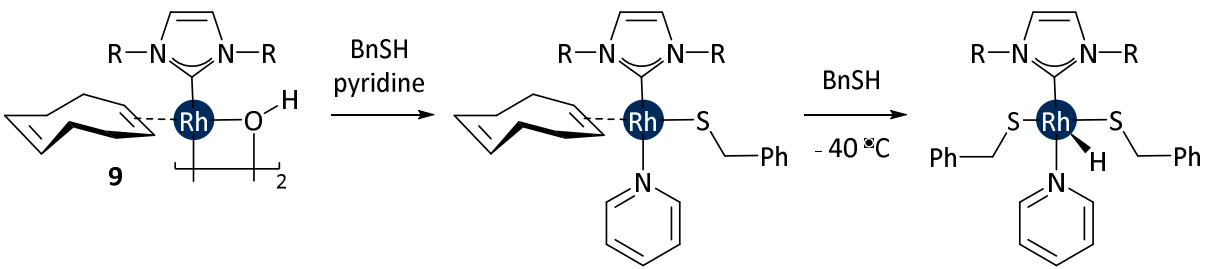

Scheme 11. Synthesis and reactions of dimeric rhodium(I) hydroxide complexes. ${ }^{36}$

A series of well-defined $[\mathrm{Rh}(\mathrm{OH})(\mathrm{COD})(\mathrm{NHC})]$ complexes were prepared either from $[\mathrm{RhCl}(\mathrm{COD})(\mathrm{NHC})]$ and caesium hydroxide, or in a one-pot procedure from $[\mathrm{Rh}(\mu-\mathrm{Cl})(\mathrm{COD})]_{2}$, free $\mathrm{NHC}$, and caesium hydroxide (Scheme 12 (a)). ${ }^{37}$ Reactivity studies have shown that these species undergo transmetallation with arylboronic acids to form well-defined [Rh(Ar)(COD)(NHC)] species; the catalytic 1,4-addition of arylboronic acids to $\alpha, \beta$-enones was also demonstrated (Scheme 12 (b)). Transmetalation was most rapid for the ICy-bearing complex (11a), as was the catalytic transformation. Hydroxide complexes 11a - 11c were also used as precursors to rhodium fluoride complexes (by reaction with $\mathrm{KHF}_{2}$ in THF) or rhodium bifluoride complexes (by reaction with $\mathrm{NEt}_{3} .3 \mathrm{HF}$ ) (Scheme $12(\mathrm{c})) .^{38}$

(a)

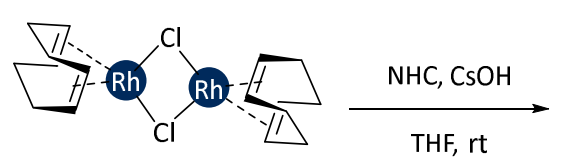

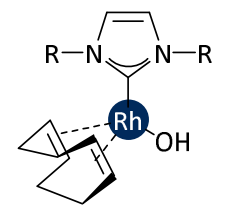

11a R - cyclohexyl (ICy)

11b R - cyclododecyl (IDD)

11c R-2,6-diisopropylphenyl (IPr)

(b)

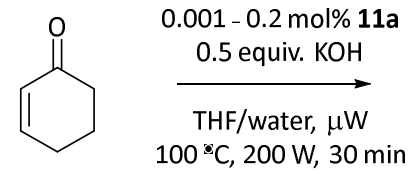<smiles>[R]c1cccc(C2CCCC(=O)C2)c1</smiles>

(c)
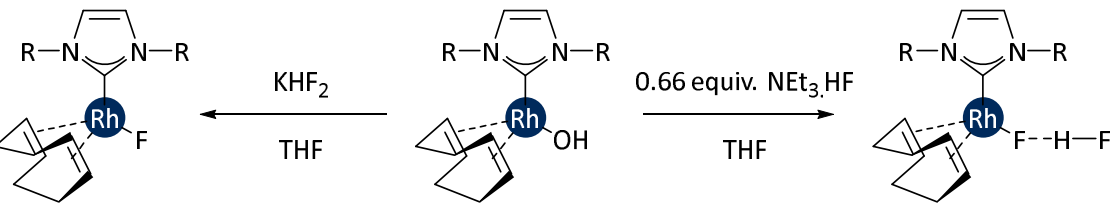

Scheme 12. Synthesis and application of NHC-bearing rhodium hydroxide complexes. ${ }^{37,} 38$

Heteropolymetallic complexes have been prepared using rhodium and iridium hydroxide complexes as starting materials. These react with palladium or platinum di(hydrosulfido) complexes to form species such as $12 .{ }^{39}$ Several different examples with different chelating NHCs were prepared 
(Scheme 13). $\left[\left(\mathrm{RhCp}^{*}\right)_{2}(\mu-\mathrm{OH})_{3}\right] \mathrm{OH}$ has also been shown to react with thymine to form substituted hydroxide-bridged rhodium dimers. ${ }^{40}$

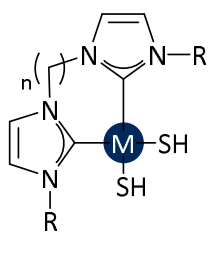

$\mathrm{M}-\mathrm{Pd}$ or Pt
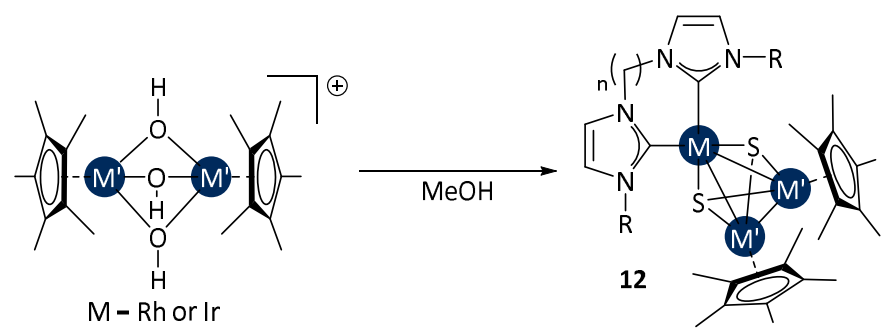

Scheme 13. Synthesis of heteropolymetallic complexes. ${ }^{39}$

\section{Iridium}

A variety of ligands have been used to support iridium hydroxide complexes, including $N$-heterocycles, pincer ligands, and NHCs. The hydroxide complexes often exist in equilibrium with the aqua complexes in aqueous solutions. For example, a porphyrin complex $\left[\operatorname{Ir}\left(\mathrm{OD}_{2}\right)_{2}(\mathrm{TSPP})\right]^{2+}$ was shown to exist in equilibrium with $\left[\operatorname{Ir}(\mathrm{OD})\left(\mathrm{OD}_{2}\right)(\mathrm{TSPP})\right]^{+}(\mathrm{pD} 7-11)$ and $\left[\operatorname{Ir}(\mathrm{OD})_{2}(\mathrm{TSPP})\right](\mathrm{pD} 11-14) .{ }^{41}$

A series of iridium(I) hydroxide complexes bearing NHC ligands has been prepared, and their reactivity has been studied systematically. ${ }^{42}$ The hydroxide complexes were prepared in a manner analogous to that of the corresponding rhodium(I) hydroxide complexes (see Scheme 12), although some water was necessary to ensure full conversion of the chloride complex to the hydroxide (Scheme 14 (a)). ${ }^{37}$ These hydroxide complexes underwent a number of reactions with sufficiently acidic $\mathrm{C}-\mathrm{H}$ and $\mathrm{E}-\mathrm{H}$ bonds $(\mathrm{E}=\mathrm{O}, \mathrm{N})$ (e.g. Scheme 14 (b)), and with silanes and boronic acids (Scheme 14 (c)). In addition, these species can be transformed into the corresponding fluoride or bifluoride complexes (for the analogous reactions with rhodium(I) hydroxides, see Scheme 12 (c)). ${ }^{38}$ Iridium(I) hydroxides, and some alkoxide and amide derivatives, undergo rapid and reversible insertion of $\mathrm{CO}_{2}$ into the iridium-oxygen bond, forming carbonate and carbamate derivatives; ${ }^{43}$ in the case of the parent hydroxide, a nuclear iridium carbonate species was formed (Scheme 14 (d)). The use of ${ }^{13} \mathrm{CO}_{2}$ demonstrated that, under an atmosphere of $\mathrm{CO}_{2}$, these complexes undergo rapid and reversible insertion/de-insertion of $\mathrm{CO}_{2}$ into the iridium-oxygen or iridium-nitrogen bond. Subsequent computational studies have elucidated the mechanism of this reaction for these and related complexes, confirming that these proceed via insertion followed by an acid/base reaction between an iridium hydrogen carbonate and the iridium hydroxide. ${ }^{44,45}$ Iridium(I) hydroxide complexes are active for the isomerisation of allylic alcohols to ketones, albeit at relatively high temperatures. ${ }^{46}$ 
(a)

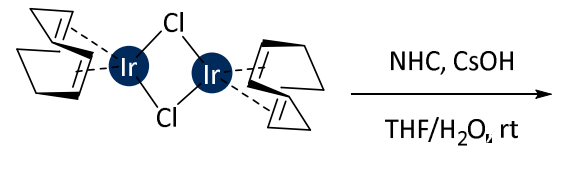

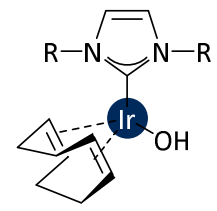

(b)
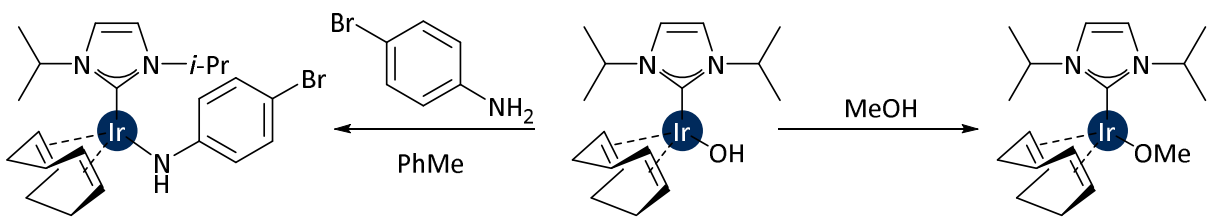

(c)
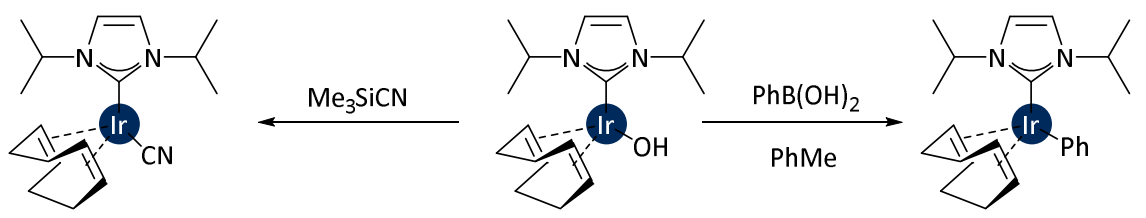

(d)

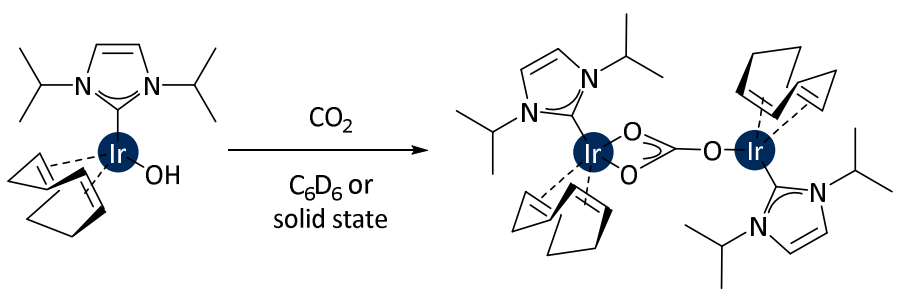

Scheme 14. Synthesis and reactions of $[\operatorname{Ir}(\mathrm{OH})(\mathrm{COD})(\mathrm{NHC})]^{42,43}$

Oro has studied the synthesis and reactions of iridium amide complexes extensively; complexes such as $\left[\operatorname{Ir}\left(\mathrm{NH}_{2}\right)(\mathrm{COD})(\mathrm{PMePh})_{2}\right]$ and $\left[\operatorname{Ir}\left(\mathrm{NH}_{2}\right)(\mathrm{COD})(\mathrm{IPr})\right]$ have been shown to react with traces of water in solvents to form the corresponding monomeric hydroxide species. ${ }^{47}$

A related bis(NHC) hydroxide complex has also been reported; $\left[\mathrm{Ir}(\mathrm{OH})(\mathrm{CO})\left(\mathrm{I}^{\mathrm{i} P \mathrm{Pr}^{\mathrm{Me}}}\right)_{2}\right](\mathbf{1 3})$ was prepared via a salt metathesis reaction from $\left[\operatorname{IrCl}(\mathrm{CO})\left(\mathrm{I}^{i} \mathrm{Pr}^{\mathrm{Me}}\right)_{2}\right]$, which was in turn prepared by

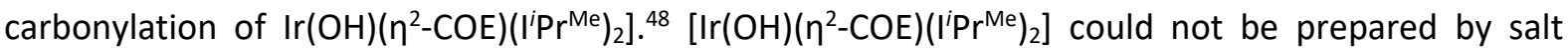
metathesis, as all attempts to do so leading to decomposition, suggesting that this species is very unstable. 13 underwent a series of bond activation reactions in a manner analogous to the complexes in Scheme 14, with concomitant changes in $v_{c o}$ for the carbonyl ligand.

Piers has reported an iridium hydroxide complex supported by a PCP ligand that undergoes reversible dehydration to form the bridging oxo-species. ${ }^{49}$ Complex 14 a was prepared by heating the corresponding chloride complex in wet THF in the presence of caesium hydroxide (Scheme 15 (a)). Applying a vacuum led to reversible dehydration to the dimeric oxo-complex; the analogous complex 14b with bulkier $P$-substituents did not undergo dehydration. Complex 14a and the oxo-complex both underwent reaction with phenols to form the corresponding phenoxide complex (Scheme 15 (b)). 
(a)
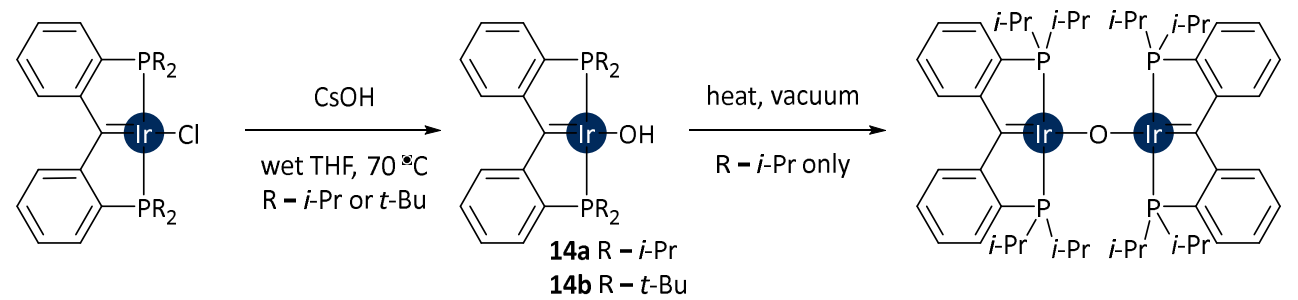

(b)

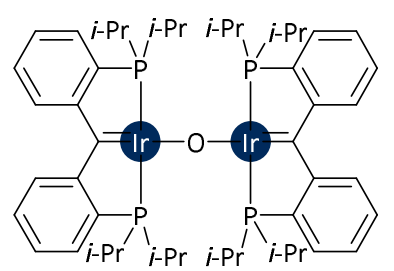

20 - 40 equiv. $\mathrm{ArOH}$
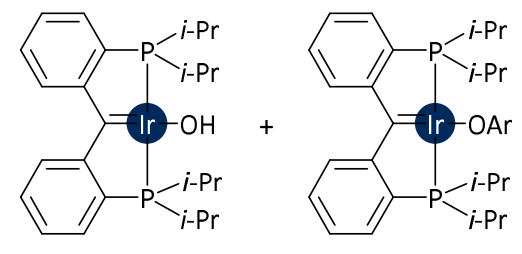

Scheme 15. Reactions of a pincer-supported iridium hydroxide complex. ${ }^{49}$

A related complex has been reported which can undergo oxidation mediated by $\mathrm{N}_{2} \mathrm{O}$ to form an iridaepoxide (Scheme 16); ${ }^{50}$ the corresponding bromide complex also showed this mode of reactivity. The two complexes show rather different reactivity towards hydrogen. The bromide undergoes oxidative addition at $-78{ }^{\circ} \mathrm{C}$ or room temperature to form well-defined dihydride species (cis- or transrespectively), while the hydroxide only reacts at room temperature but with reduction of the iridaepoxide moiety. 


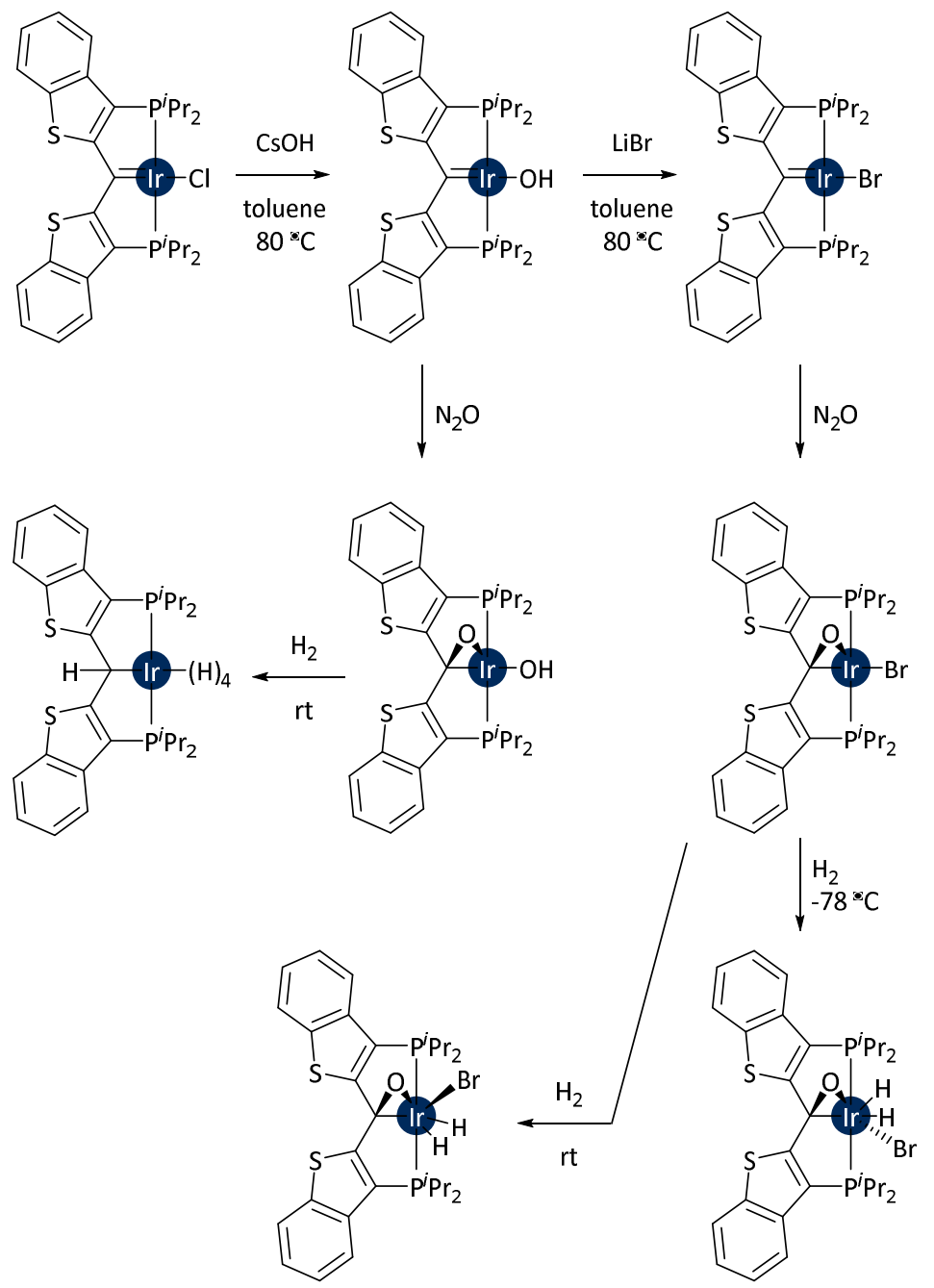

Scheme 16. Synthesis and reactivity of iridaepoxide complexes..$^{50}$

Iridium hydroxide complexes have been prepared from the reaction of iridium phenyl species with molecular oxygen (Scheme 17). ${ }^{51}$ Complex 15, supported by a PNP ligand, reacts with $\mathrm{O}_{2}$ at low temperatures with concomitant dearomatisation of the ligand; evidence for intermediate $\mathbf{1 6}$ was provided from trapping experiments with carbon monoxide, which led to an iridium carbonate complex (17) at low temperatures.
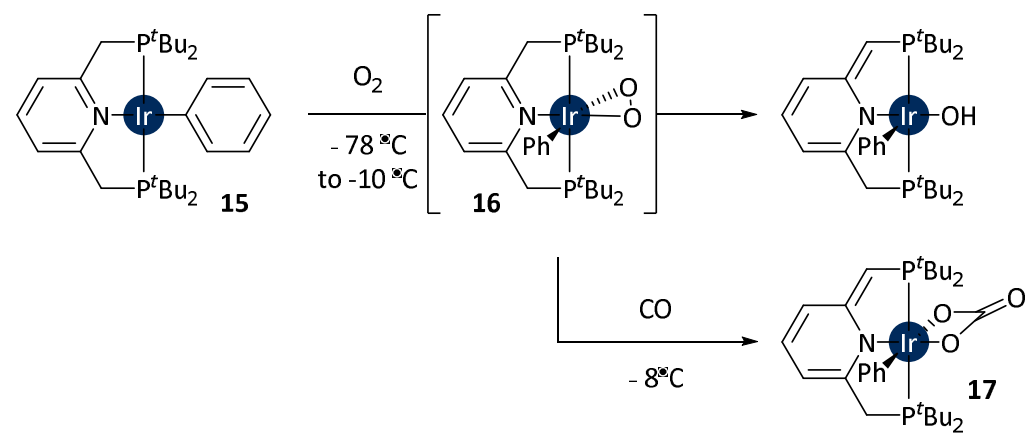

Scheme 17. Reaction of an iridium phenyl complex with molecular oxygen. ${ }^{51}$ 


\section{Group 10: Nickel, Palladium, and Platinum}

\section{Nickel}

A number of nickel hydroxide complexes have been prepared from reactions involving oxygen. In a series of manuscripts, Sigman reported that $\left[\mathrm{Ni}\left(\eta^{3}\right.\right.$-allyl)Cl(NHC)] and $\left[\mathrm{Ni}\left(\eta^{3}\right.\right.$-cinnamyl)Cl(NHC)] complexes react with air to form dimeric complexes with bridging hydroxide ligands (Scheme 18 (a)). ${ }^{52-}$ ${ }^{54}$ The allyl (or cinnamyl) ligand is oxidised to the corresponding enal or enone. It was proposed that the reactivity with oxygen was correlated to the flexibility of the NHC ligand, with less flexible ligand being less reactive with oxygen. The $\mathrm{Ni}^{\prime}$ dimer $[\mathrm{Ni}(\mu-\mathrm{Cl})(\mathrm{IPr})]_{2}$ underwent reaction with oxygen to form an analogous species in which the ligand had been spontaneously dehydrogenated (Scheme 18 (b)). Whittlesey has studied the reactions of $\mathrm{Ni}^{\prime}$ complexes $\left[\mathrm{NiBr}\left(\mathrm{PPh}_{3}\right)(\mathrm{reNHC})\right]$ where reNHC is a ringexpanded NHC based on a six-, seven-, or eight-membered core. ${ }^{55}$ For examples with an $\mathrm{N}$-mesityl substituent, C-H activation of the mesityl ortho-methyl group occurred, leading to complexes with bridging alkoxide and hydroxide ligands (Scheme 18 (c)).

(a)
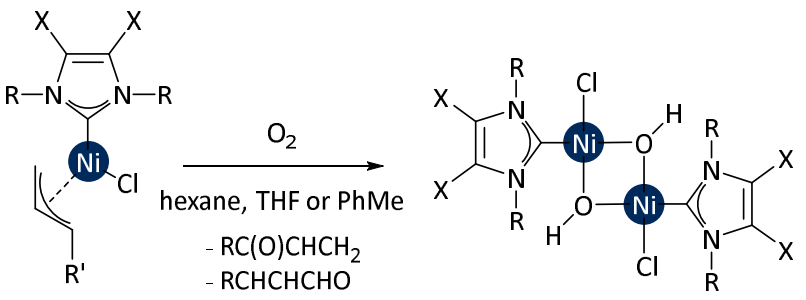

(b)
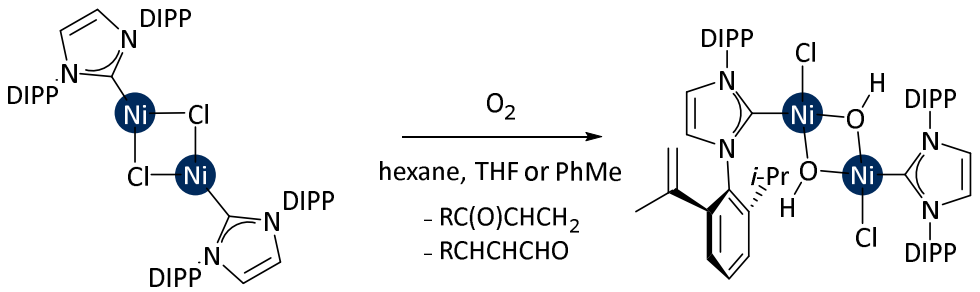

(c)

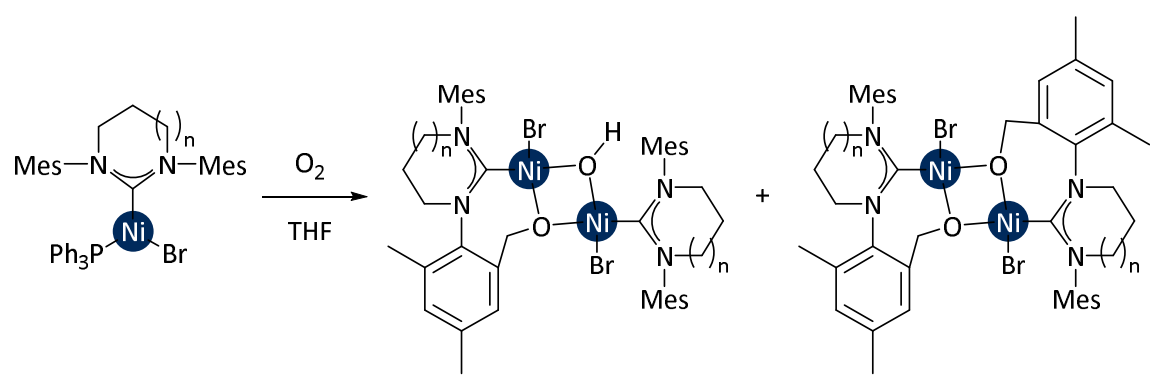

Scheme 18. Reactions of NHC-nickel complexes with molecular oxygen. ${ }^{52-55}$

Nickel hydroxide complexes have been implicated in nickel-catalysed cross-coupling reactions, ${ }^{3}$ in much the same way as it is now believed that palladium hydroxide complexes are the key intermediates in palladium-catalysed Suzuki-Miyaura reactions. ${ }^{56}$ The reaction between an 
isolated nickel hydroxide complex and a boronic acid was demonstrated to occur more rapidly than the reaction between the analogous nickel halide complex and a pre-formed boronate reagent.

A nickel hydroxide complex supported by a PCP ligand has been prepared by salt metathesis from the corresponding nickel chloride, and by reaction of the amide complex with wet THF (Scheme 19 (a)). ${ }^{57}$ The amide complex was in turn prepared by salt metathesis using $\mathrm{NaNH}_{2}$. While the amide complex was studied in more depth, a number of reactions were carried out with the hydroxide species, such as transmetalation with silanes to form cyanide and azide complexes (Scheme 19 (b)). The hydroxide species can also trap $\mathrm{CO}_{2}$ (even at relatively low pressures), leading to a nickel carbonate complex (Scheme 19 (c)). This carbonate complex remains monomeric, unlike NHCirdium $\left(I^{43}\right.$ (vide supra) and $\mathrm{NHC}$-gold(I) ${ }^{58}$ examples (vide infra), which dimerise or trimerise, respectively. Other nickel complexes, with bridging hydroxide moieties, have also been reported to trap $\mathrm{CO}_{2}$ in the form of carbonate ligands. ${ }^{59}$

(a)<smiles>CC(C)(C)P12=NC3=C(Cl)Cc4cccc(c43)CP1(C(C)(C)C)(C(C)(C)C)C2</smiles>

(b)<smiles>CC(C)(C)P12(C(C)(C)C)Cc3cccc4c3-c3cccc(c3N(C#N)P(C4)C1)C2</smiles>
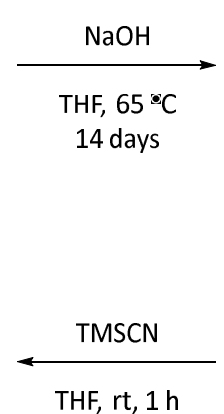

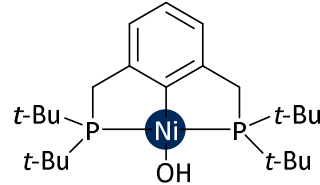

$t-\mathrm{Bu}^{\prime} \quad \mathrm{OH} \quad \mathrm{t}-\mathrm{Bu}$

(b)

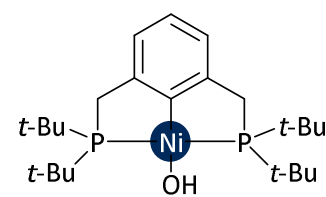

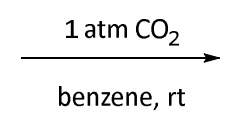

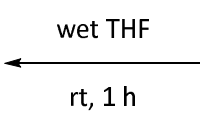

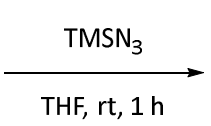

Scheme 19. Synthesis and reactivity of a PCP-supported nickel hydroxide complex. ${ }^{57}$

$[\mathrm{Ni}(\mu-\mathrm{OH})(\text { dippe })]_{2}{ }^{2+}$ was identified as an intermediate in the reduction of $\left[\mathrm{NiCl}_{2}(\right.$ dippe $\left.)\right]$ to $\left[\mathrm{Ni}(\text { dippe })_{2}\right]$ using $\mathrm{KOH} .{ }^{60}$ Tris(pyrazolyl)borate-supported nickel hydroxide complexes have also been used in tandem with an iridium complex for the formation of $n$-butanol from ethanol. ${ }^{61}$

\section{Palladium}

Palladium complexes with $\mathrm{C}, \mathrm{N}$-ligands are readily prepared and can be used as precursors for other complexes. ${ }^{62,63}$ For example, benzoylpyridine-supported palladium acetate dimers are converted to 
the corresponding dimeric hydroxide by reaction with tetra( $n$-butyl)ammonium hydroxide. ${ }^{64}$ This can then react with an NHC to form well-defined monomeric palladium hydroxide species (Scheme 20). Other derivatives that have been prepared from these hydroxide complexes have shown luminescence behaviour that could potentially be harnessed in a number of applications. ${ }^{65,66}$

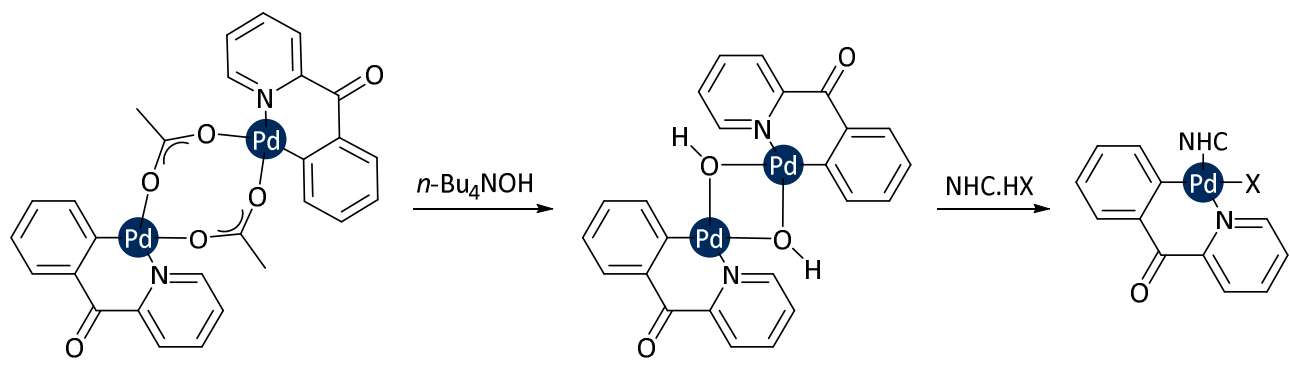

Scheme 20. Synthesis and reactivity of benzoylpyridine-supported palladium hydroxide complexes. ${ }^{64}$

Palladium hydroxide complexes supported by PCN ligands have been found to undergo 'rollover' C-H activation processes (Scheme 21). ${ }^{67} \mathrm{~A}$ dimeric complex with a bridging hydroxide ligand was formed by salt metathesis from the monomeric triflate species; this then underwent further reaction to form the $\mathrm{C}-\mathrm{H}$ activated species 18.
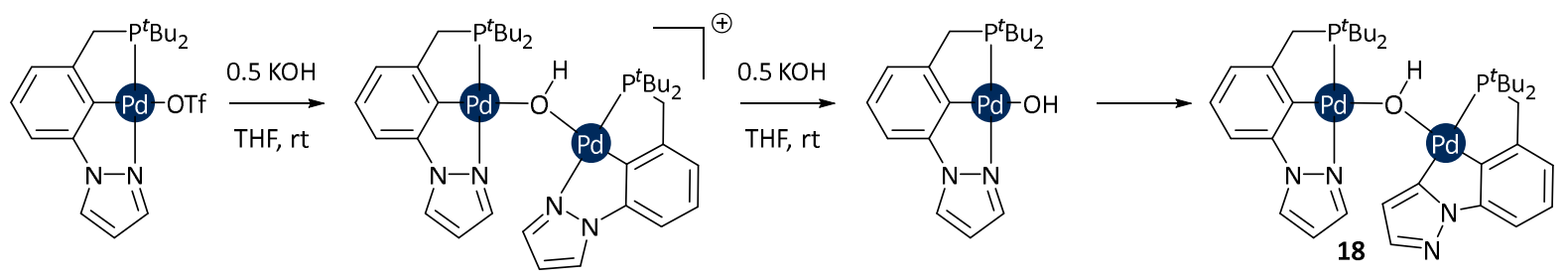

Scheme 21. Synthesis and reactivity of a palladium hydroxide complex supported by a PCN ligand. ${ }^{67}$

Complexes of the form $[\mathrm{PdCl}($ cinnamyl)(NHC)] are widely used in catalysis, but these can undergo reaction with caesium hydroxide to form hydroxide bridged dimers in which the allyl ligand rearranges from $\eta^{3}$ to $\mathrm{k}$-coordination (Scheme 22). ${ }^{68}$ These remain active for transformations including Buchwald-Hartwig and Suzuki-Miyaura cross-coupling reactions. When these complexes were placed under a hydrogen atmosphere, the allyl ligand was hydrogenated to $n$-propylbenzene; $\left[\mathrm{Pd}(\mathrm{NHC})_{2}\right]$ complexes were also identified amongst the products. 

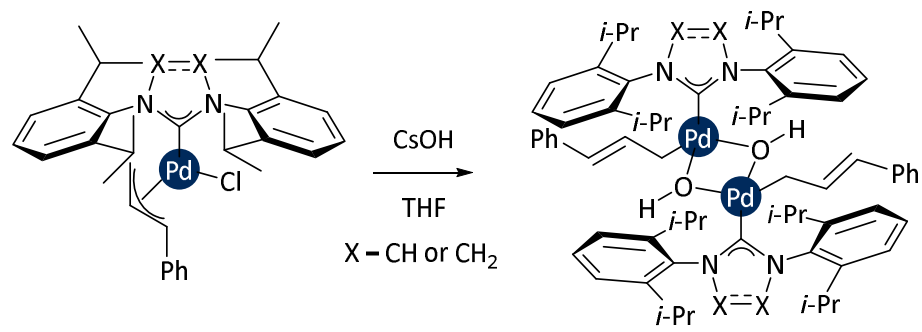

Scheme 22. Synthesis of hydroxide-bridged palladium dimers. ${ }^{68}$

While salt metathesis is the most common route to palladium hydroxide complexes, these can also be prepared by reaction of a suitable precursor with oxygen. $\left[\mathrm{Pd}\left(\mathrm{P}^{t} \mathrm{Bu}_{2} \mathrm{Nap}_{2}\right]\right.$ is oxidised by $\mathrm{O}_{2}$ to form a hydroxide-bridged palladium(II) dimer in which the peri-position of the napthyl fragment has been metalated (Scheme 23). ${ }^{69}$ In contrast, [ $\mathrm{Pd}(\mathrm{OH})(\mathrm{Me})(\mathrm{di}(2$-pyridyl)methane sulfonate)] undergoes reaction with oxygen to form $\left[\mathrm{Pd}(\mathrm{OH})_{2}(\mathrm{di}(2\right.$-pyridyl)methane sulfonate) $]$ and a mixture of methanol, ethane, and methyl peroxide. ${ }^{70}$

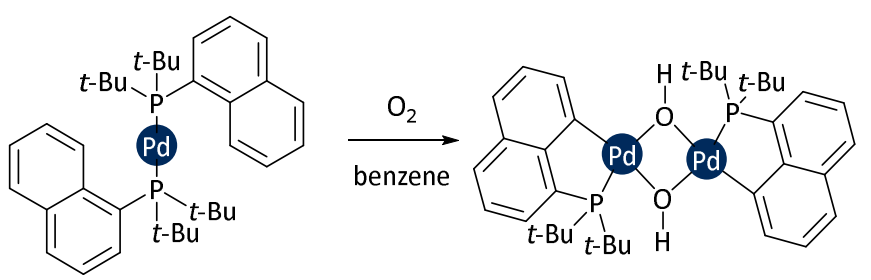

Scheme 23. Oxidation of a palladium(0) complex with oxygen to form a C-H activated product. ${ }^{69}$

The majority of known palladium hydroxide complexes feature palladium in the +2 oxidation state, but examples of palladium(IV) hydroxide complexes have also been reported. An example of such a species has been prepared from the reaction of a palladium(II) complex with oxygen (Scheme 24). ${ }^{71}$ This was proposed to occur via the formation of an intermediate peroxide species. Further heating of the hydroxide complex $\left(110^{\circ} \mathrm{C}\right.$ in DMSO) led to $\mathrm{C}$-O reductive elimination and the formation of 2 -(tertbutyl)phenol. These complexes were supported by a flexible amine ligand ("Mestacn") that is bidentate in the palladium(II) precursor, but changes to become tridentate in the palladium(IV) species, which may explain the relatively facile oxidation of the palladium centre.

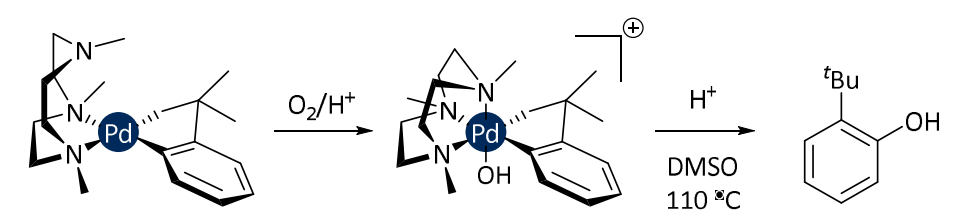

Scheme 24. Synthesis of, and reductive elimination from, a well-defined palladium(IV) hydroxide species. $^{71}$ 
Like many metal hydroxide species, palladium hydroxide complexes have been demonstrated to be competent to activate molecules with sufficiently low $\mathrm{pK}_{\mathrm{a}}$. One of the most promising studies was the activation of fluoroform $\left(\mathrm{HCF}_{3}\right)$ using a $[\mathrm{Pd}(\mathrm{OH})(\mathrm{Ph})(\mathrm{dppp})]$ in the presence of $\mathrm{P}^{n} \mathrm{Bu}_{3} ;{ }^{72}$ the added phosphine was essential for the reaction to occur, but catalytic quantities could be used (15 mol\%) (Scheme 25). In addition, the reaction was acutely sensitive to the choice of ligand, with dppp giving good yields, dppe providing some product, and other phosphines yielding disappointing results. This fluoroform activation reaction could be envisioned as key step in a putative catalytic trifluoromethylation reaction using readily-available fluoroform as the $\mathrm{CF}_{3}$ source.

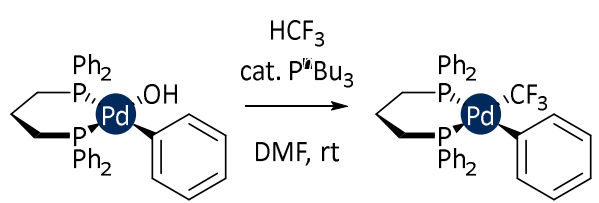

Scheme 25. Activation of fluoroform using a palladium hydroxide complex. ${ }^{72}$

There are many examples of well-defined palladium hydroxide complexes, but possibly the most important role of such species is as intermediates in palladium-catalysed Suzuki cross-couplings. This area has recently been reviewed. ${ }^{56}$ Recently, key intermediates in which the palladium hydroxide species has activated the boronic acid before transmetallation have been identified and characterised spectroscopically (Scheme 26). ${ }^{73,74}$

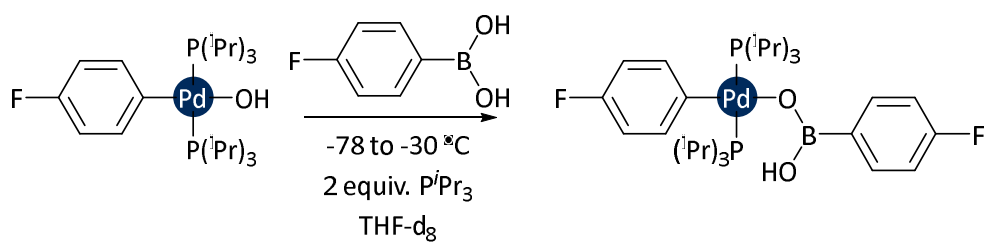

Scheme 26. A pre-transmetallation intermediate in Suzuki-Miyaura cross-coupling. ${ }^{73,74}$

This mode of reactivity has been exploited to achieve Suzuki-Miyaura cross-coupling reactions under base-free conditions. ${ }^{75}$ Pd-PEPPSI-IPr undergoes reaction with potassium hydroxide to form complex 19, which shows comparable activity to Pd-PEPPSI-IPr and $[\mathrm{PdCl}(\mu-\mathrm{Cl})(\mathrm{IPr})]_{2}$ under the same reaction conditions (Scheme 27). However, under base-free conditions, only $\mathbf{x x}$ shows catalytic turnover. This may be a viable and useful method to achieve the Suzuki-Miyaura cross-coupling of substrates that might be somewhat sensitive to base. 
(a)
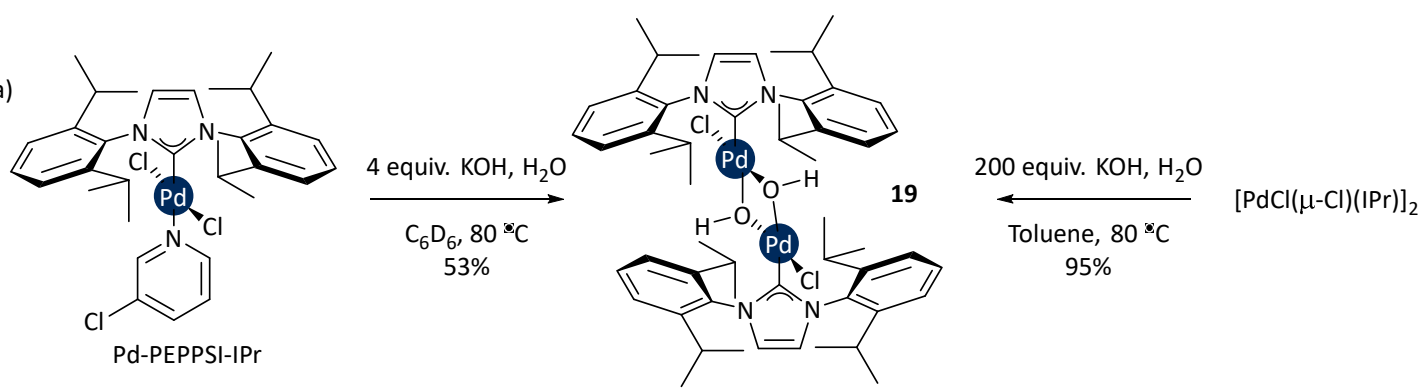

(b)

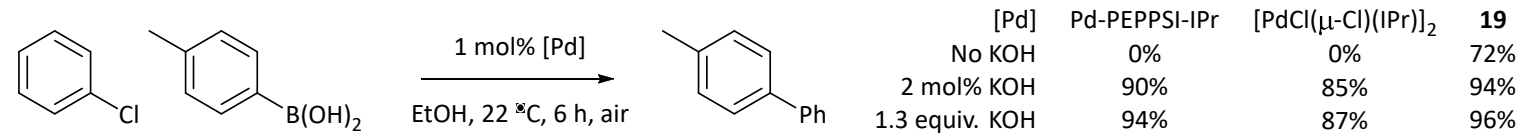

Scheme 27. (a) Synthesis of a hydroxide-bridged palladium complex. (b) Application of 19 in SuzukiMiyaura cross-coupling reactions.

\section{Platinum}

Platinum hydroxide complexes are relatively common, and have been reviewed recently, ${ }^{76}$ so only selected examples of such complexes are discussed here.

Extremely bulky diimine ligands have been used to allow the isolation of platinum(IV) hydroxide species. The reaction conditions used allowed the selective preparation of the mono- or dihydroxide species (Scheme 28). ${ }^{77}$ The use of a less bulky and rigid ligand, in which methyl groups were present on the imine backbone rather than a peri-naphthalene group, led to decomposition when the synthesis of the hydroxide complex was attempted.
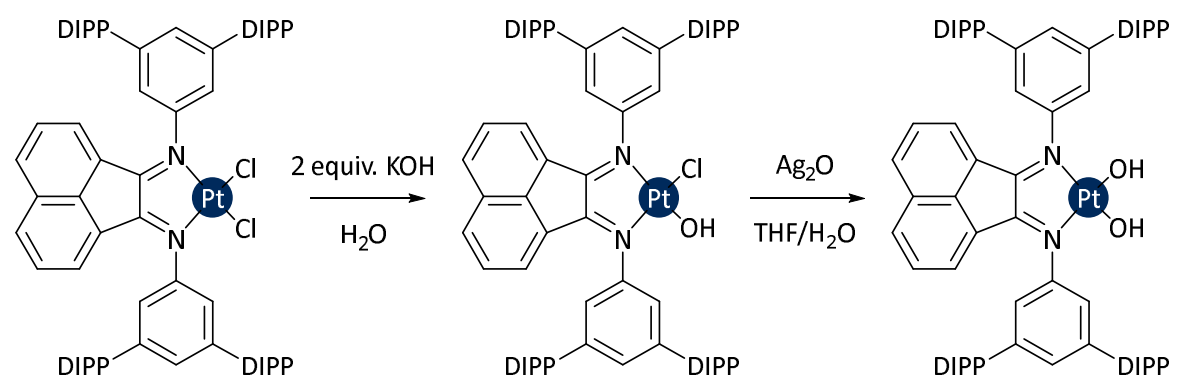

Scheme 28. Synthesis of mono- and di-hydroxoplatinum(IV) species. ${ }^{77}$

A terpy-supported platinum(II) methylperoxo complex was found to undergo reaction to form formaldehyde and a platinum(II) hydroxide species (Scheme 29). ${ }^{78}$ Interestingly, this deviated from the reactivity of the corresponding palladium complex, which eliminated methylperoxide instead. This illustrates that, while there are some common aspects of the reactivity of late transition metal hydroxide complexes, the identity of the metal also plays a key role in determining the preferred reaction pathway. 


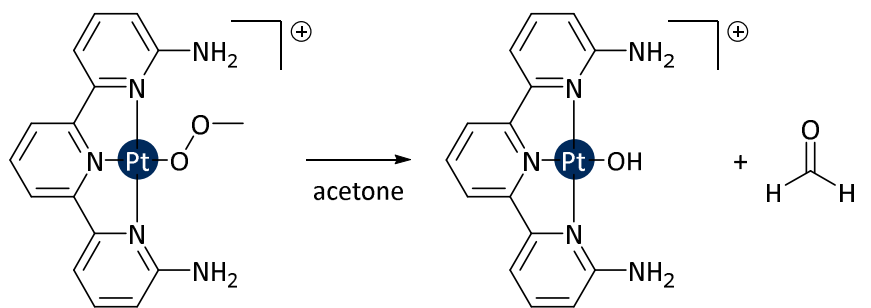

Scheme 29. Elimination of formaldehyde from a platinum(II) methylperoxo complex. ${ }^{78}$

Platinum hydroxide complexes might play a role in a number of putative catalytic cycles. The reductive elimination of methanol from $\left[\mathrm{PtMe}_{3}(\mathrm{OH})(\mathrm{dppb})\right]$ has been demonstrated, for example, and this might conceivably comprise part of a catalytic cycle for methane oxidation to methanol. ${ }^{79}$ 


\section{Group 11: Copper, Silver, and Gold}

\section{Copper}

Of the known and well-defined copper hydroxide complexes, species of the form $[\mathrm{Cu}(\mathrm{OH})(\mathrm{NHC})]$ are amongst the most widely studied. ${ }^{80}$ These can be prepared from [CuCl(NHC)] by salt metathesis using $\mathrm{CsOH}$ (Scheme 30). These species will react with sufficiently acidic $\mathrm{CH}$ bonds to form a variety of new compounds. Substrates including $\mathrm{MeNO}_{2}$, dimethyl malonate, 1,2,4,5-tetrafluorobenzene, terminal alkynes, alcohols, thiols, and secondary phosphines all undergo reaction (Scheme 29). ${ }^{81}$ The reaction with cyclopentadiene yielded the half-sandwich complex $[\mathrm{Cu}(\mathrm{Cp})(\mathrm{NHC})]$. Based on the $\mathrm{pK}_{\mathrm{a}}$ range of the groups that undergo reaction, it appears that species with $\mathrm{pK}_{\mathrm{a}}$ up to $c a .27-30$ are viable reagents. As well as exhibiting deprotonation reactivity, these species will undergo transmetallation with silanes. Somewhat similar reactivity has also been observed with $\left[\mathrm{Cu}\left(\mathrm{O}^{t} \mathrm{Bu}\right)(\mathrm{NHC})\right]$ complexes. ${ }^{82}$ Notably, mesoionic triazolylidene-bearing copper chloride complexes cannot be transformed into the corresponding copper hydroxide complexes, as reaction with $\mathrm{CsOH}$ leads instead to decomposition of the complex; ${ }^{83}$ the supporting ligand environment is therefore important.

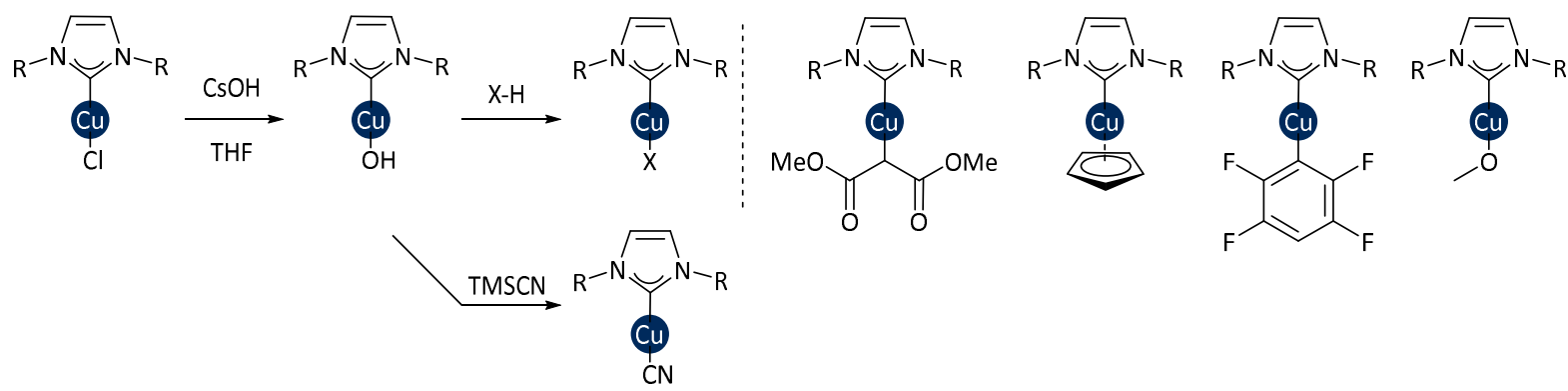

Scheme 30. Synthesis and reactivity of $[\mathrm{Cu}(\mathrm{OH})(\mathrm{IPr})]$, with selected examples of the products formed $\left(\mathrm{R}=2,6\right.$-diisopropylphenyl). ${ }^{80}$

These copper hydroxide complexes have been applied in a number of catalytic reactions (Scheme 31 illustrates some examples). [Cu(OH)(IPr)] will catalyse the carboxylation of various $\mathrm{C}-\mathrm{H}$ and $\mathrm{N}-\mathrm{H}$ bonds using $\mathrm{CO}_{2}$ at rather low pressures, allowing access to a range of carboxylic acids and carbamates; ${ }^{84}$ the key steps are proposed to be activation of the substrate and then $\mathrm{CO}_{2}$ insertion into the $\mathrm{Cu}-\mathrm{C}$ or $\mathrm{Cu}-\mathrm{N}$ bond. A similar procedure using $\left[\mathrm{Cu}\left(\mathrm{O}^{t} \mathrm{Bu}\right)(\mathrm{IPr})\right]$ was reported around the same time,$^{85}$ and the process has been investigated using DFT calculations. ${ }^{86}$ Copper hydroxide complexes have been used (catalytically) in tandem with palladium catalysts to achieve the cross-coupling of arenes with aryl halides. ${ }^{87}$ The copper complex activates the arene, which then undergoes transmetallation with palladium to complete a cross-coupling catalytic cycle. $[\mathrm{Cu}(\mathrm{OH})(\mathrm{IPr})]$ is also active for the semihydrogenation of alkynes, ${ }^{88}$ enynes, or diynes ${ }^{89}$ using hydrogen or ammonia borane, ${ }^{90}$ with high selectivity for the Z-alkene or diene products. When used in tandem with 
[Au(OTf)(IPr)], [Cu(OH)(IPr)] can activate phenols for the hydrophenoxylation of alkynes, by forming $[\mathrm{Cu}(\mathrm{OAr})(\mathrm{IPr})]$ intermediates which then react with $[\mathrm{Au}(\mathrm{IPr})(\text { alkyne })]^{+}$complexes; ${ }^{91}$ a variant involving two gold catalysts is also known (vide infra). ${ }^{92}[\mathrm{Cu}(\mathrm{OH})(\mathrm{IPr})]$ was used alongside an iridium complex for the formation of $n$-butanol from ethanol. ${ }^{61}$
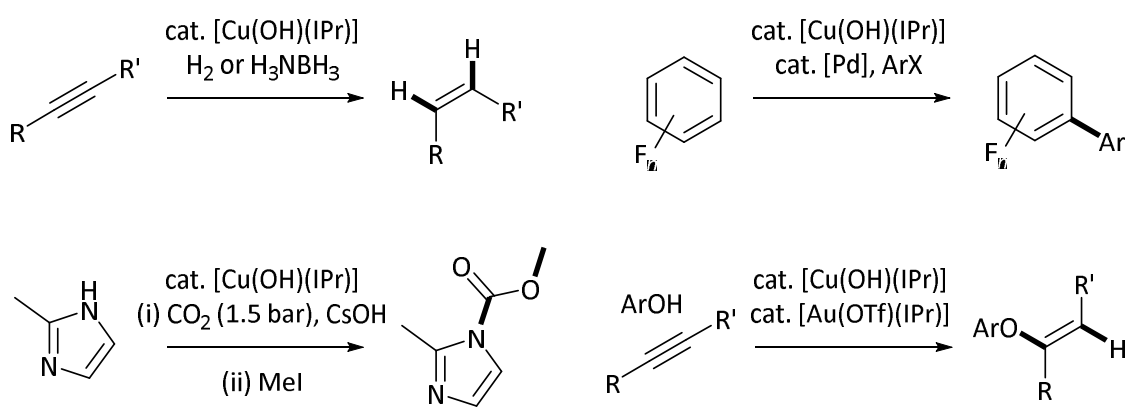

Scheme 31. Selected examples of catalytic applications of copper(I) hydroxide complexes in catalysis.

As well as applications in catalysis, $[\mathrm{Cu}(\mathrm{OH})(\mathrm{NHC})]$ complexes have been used as intermediates en route to a number of other functional and useful complexes. These include luminescent metal complexes that are promising for lighting and display applications, ${ }^{93,94}$ and bis(NHC) complexes with applications in catalysis. ${ }^{95,} 96[\mathrm{Cu}(\mathrm{OH})(\mathrm{NHC})]$ complexes will activate triazole to form $[\mathrm{Cu}(\mu-$ triazole)(NHC)$]_{2}$ species which were used for the transfer hydrogenation of carbonyl compounds. ${ }^{97}$

While most stoichiometric and catalytic work has been carried out using NHC-supported copper complexes prepared by salt metathesis, there are other examples of copper hydroxide species. Copper hydroxide complexes have been shown to interact with various biomolecules, including intercalation into, and cleavage of, DNA (Scheme 32); ${ }^{98}$ a mechanism has been proposed that relies on the cleavage of the phosphate backbone via nucleophilic attack by the hydroxide ligand. Copper(I) hydroxide was formed in the reaction between $\left[\mathrm{Pt}\left(\mathrm{P}^{t} \mathrm{Bu}_{3}\right)_{2}\right]$ and $\left[\mathrm{Cu}(\mathrm{NCMe})_{4}\right]\left[\mathrm{PF}_{6}\right]$ from the cooperative cleavage of water; ${ }^{99}$ a datively coordinated $\mathrm{Pt}-\mathrm{Cu}$ complex was proposed as an intermediate. 


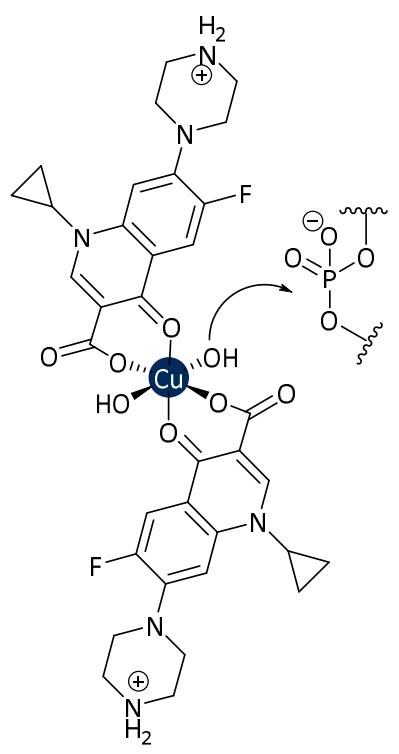

Scheme 32. Proposed mechanism for DNA cleavage by a copper hydroxide complex.

\section{Silver}

There are relatively few well-characterised examples of silver hydroxide complexes, although these have been proposed as intermediates in the synthesis of bis(NHC) silver $(\mathrm{I})$ complexes from $[\mathrm{AgCl}(\mathrm{NHC})]$ starting materials. ${ }^{96}$ One example was reported by Liu and co-workers, and was characterised by NMR spectroscopy and X-ray crystallography (Scheme 33); ${ }^{100}$ this was prepared directly from the imidazolium salt plus silver(I) acetate and potassium hydroxide.

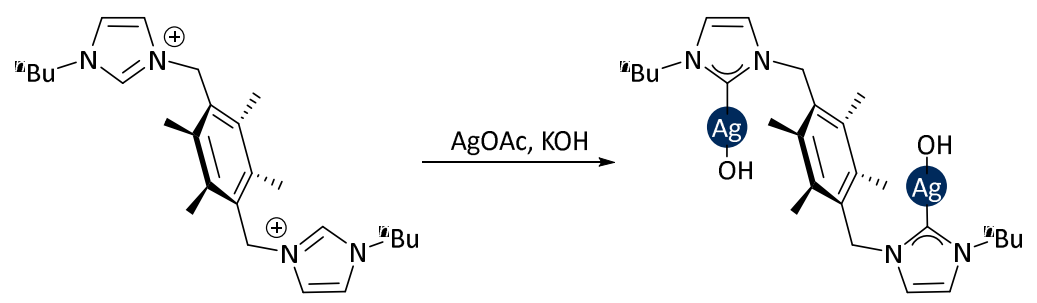

Scheme 33. Synthesis of a silver(I) hydroxide complex. ${ }^{100}$

\section{Gold}

The chemistry of gold hydroxide complexes has been widely explored and developed in recent years, particularly for species such as, or derived from $[\mathrm{Au}(\mathrm{OH})(\mathrm{NHC})]{ }^{81,101}$ The first complex of this type was reported in 2010, and was prepared by salt metathesis using $\mathrm{NaOH}, \mathrm{KOH}$, or $\mathrm{CsOH}$ (Scheme 34). Further complexes of this type have since been reported, although those with less bulky NHC ligands tend to be air sensitive. ${ }^{102,103}$ In addition, a number of alternative routes to these complexes have been developed, but the key step is usually the exchange of a halide ligand for a hydroxide ligand. ${ }^{104-}$ ${ }^{106}$ However, it has been shown that $[\mathrm{Au}(\mathrm{OOH})(\mathrm{IPr})]$ will transfer an oxygen atom to phosphines to 
form $[\mathrm{Au}(\mathrm{OH})(\mathrm{IPr})]$ (vide infra). ${ }^{107,} 108$ The reactivity of these complexes has been mapped out in some detail (late schemes illustrate selected examples). $[\mathrm{Au}(\mathrm{OH})(\mathrm{NHC})]$ complexes have also been investigated as potential anticancer agents. ${ }^{109}$

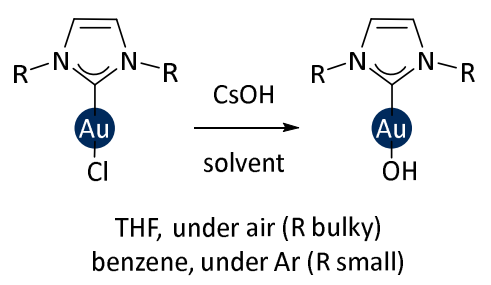

Scheme 34. Synthesis of $[\mathrm{Au}(\mathrm{OH})(\mathrm{NHC})]$ complexes. ${ }^{101,102}$

As noted above for the analogous copper species, $[\mathrm{Au}(\mathrm{OH})(\mathrm{NHC})]$ will deprotonate a range of different substrates, typically when the $\mathrm{pK}_{\mathrm{a}}$ is less than ca. 30 units. ${ }^{4}$ Reactions with amine or pyridinium salts form cationic species such as $\left[\mathrm{Au}(\mathrm{NHC})\left(\mathrm{NR}_{3}\right)\right]^{+}$and $[\mathrm{Au}(\mathrm{py})(\mathrm{NHC})]^{+}$, respectively. ${ }^{110}$ Similarly, reactions between $[\mathrm{Au}(\mathrm{OH})(\mathrm{NHC})]$ and $\mathrm{NHC}^{\prime} . \mathrm{HX}$ or $\mathrm{R}_{3} \mathrm{P} . \mathrm{HX}$ yield $\left[\mathrm{Au}(\mathrm{NHC})\left(\mathrm{NHC}^{\prime}\right)\right]^{+}$and $\left[\mathrm{Au}(\mathrm{NHC})\left(\mathrm{PR}_{3}\right)\right]^{+}$species, respectively. ${ }^{111}$ These complexes will deprotonate acetylenes ${ }^{112}$ and phenols, ${ }^{113}$ even in the solid state, and therefore allow access to a range of new complexes that are of relevance to catalysis or lead to functional new materials. Anilines are deprotonated to yield $\left[\mathrm{Au}\left(\mathrm{NAr}_{2}\right)(\mathrm{NHC})\right]$ species that have interesting photophysical behaviour. ${ }^{114}$ Acetone is smoothly deprotonated, leading to metalation at the carbon, rather than formation of a gold enolate; ${ }^{115}$ this product is also catalytically-active (e.g. in alkyne hydrogenation) when activated by acid, and can deprotonate a range of substrates. $[\mathrm{Au}(\mathrm{OH})(\mathrm{NHC})]$ deprotonate tert-butylperoxide to form $\left[\mathrm{Au}\left(\mathrm{OO}^{t} \mathrm{Bu}\right)(\mathrm{NHC})\right]$ species; ${ }^{107}$ these can transfer oxygen to phosphines to re-form the hydroxide. ${ }^{107}$, ${ }^{108}$ Scheme 35 illustrates selected examples of the reactivity of gold(I) hydroxide complexes in which water is liberated. 


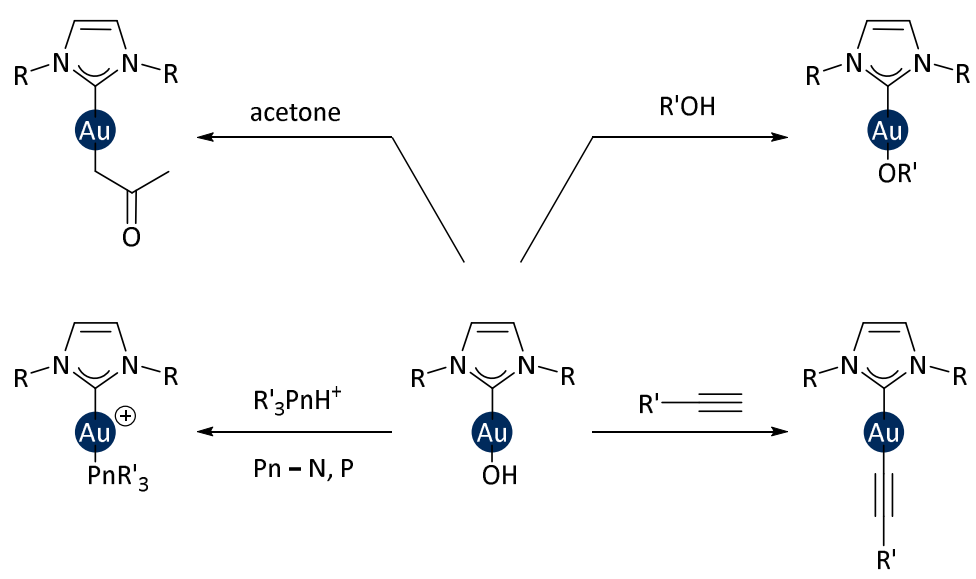

Scheme 35. Selected examples of the reactivity of $[\mathrm{Au}(\mathrm{OH})(\mathrm{NHC})]$ complexes with sufficiently acidic substrates.

Transmetallation reactions with silanes and boronic acids have both been studied in some depth (e.g. Scheme 36). Arylboronic acids transmetalate to $[\mathrm{Au}(\mathrm{OH})(\mathrm{IPr})]$ rapidly (within a few minutes at room temperature) to form $[\mathrm{Au}(\mathrm{Ar})(\mathrm{IPr})] \cdot{ }^{116} \mathrm{At}$ room temperature, $\mathrm{RSi}(\mathrm{OMe})_{3}(\mathrm{R}=$ alkyl or aryl) react with $[\mathrm{Au}(\mathrm{OH})(\mathrm{IPr})]$ to form $\left[\mathrm{Au}\left(\mathrm{OSi}(\mathrm{OMe})_{2} \mathrm{R}\right)(\mathrm{IPr})\right]$ complexes rather quickly in an exothermic process $\left(\Delta \mathrm{H}\right.$ was measured at $-10.5(5) \mathrm{kcal} \mathrm{mol}^{-1}$ by calorimetry), but $\mathrm{ArSiMe}_{3}$ are unreactive. ${ }^{117}$ Prolonged heating of these products led to $[\mathrm{AuR}(\mathrm{IPr})]$ species, but these could be formed more quickly by heating the reaction of $\mathrm{RSi}(\mathrm{OMe})_{3}$ with $[\mathrm{Au}(\mathrm{OH})(\mathrm{IPr})]$; later computational studies suggest that the silanoate is not an intermediate in transmetallation, and that the barrier for direct reaction between the two compounds is lower. ${ }^{118}$

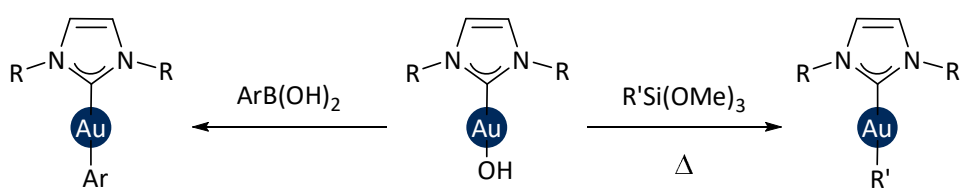

Scheme 36. Selected examples of transmetalation to $[\mathrm{Au}(\mathrm{OH})(\mathrm{NHC})]$.

Reactions between $[\mathrm{Au}(\mathrm{OH})(\mathrm{NHC})]$ and carbon dioxide are particularly interesting. ${ }^{58}$ These species react with $\mathrm{CO}_{2}$ to form a mixture of complexes; in the presence of a source of $[\mathrm{Au}(\mathrm{IPr})]^{+}$they converge upon $\left[(\mathrm{Au}(\operatorname{IPr}))_{3}\left(\mu^{3}-\mathrm{CO}_{3}\right)\right]^{+}$which was isolated and characterised crystallographically. DFT calculations support a mechanism involving $\mathrm{CO}_{2}$ insertion into the $\mathrm{Au}-\mathrm{O}$ bond, followed by condensation of $[\mathrm{Au}(\mathrm{OH})(\mathrm{IPr})]$ and $\left[\mathrm{Au}\left(\mathrm{OCO}_{2} \mathrm{H}\right)(\mathrm{IPr})\right]$ and coordination of $[\mathrm{Au}(\mathrm{IPr})]^{+}$. Similar complexes have been reported by Bertrand from the reaction of $\left[\mathrm{Au}\left(\mathrm{OSiMe}_{3}\right)(\mathrm{IPr})\right]$ and $[\mathrm{Au}(\mathrm{OTf})(\mathrm{IPr})]$ with $\mathrm{CO}_{2} \cdot{ }^{119}$

The catalytic applications of $[\mathrm{Au}(\mathrm{OH})(\mathrm{IPr})]$ largely follow from their observed stoichiometric reactivity. Carboxylation reactions of sufficiently acidic arenes have been achieved using [Au(OH)(IPr)] 
under an atmosphere of $\mathrm{CO}_{2}$ and in the presence of additional base. ${ }^{4}$ The reverse reaction also takes place, albeit under relatively forcing conditions. ${ }^{120}$ Key steps in this reaction have been studied in some depth experimentally and with the aid of DFT calculations. ${ }^{121}$

$[\mathrm{Au}(\mathrm{OH})(\mathrm{NHC})]$ complexes can be activated using acid, precluding the need for silver additives in synthetic applications such as hydration, hydroamination, hydrophosphoryloxylation, and rearrangement reactions. ${ }^{122-124}$

When $[\mathrm{Au}(\mathrm{OH})(\mathrm{NHC})]$ reacts with half an equivalent of a non-coordinating acid (such as $\mathrm{HBF}_{4}$ ), dimeric digold hydroxide species $\left[(\mathrm{Au}(\mathrm{NHC}))_{2}(\mu-\mathrm{OH})\right]^{+}$can be isolated (Scheme 37). ${ }^{122,125} \mathrm{~A}$ range of such species have now been prepared, and have played a role in the developing area of digold catalysis. ${ }^{126,} 127$ In contrast, reactions with mineral acids such as $\mathrm{HNO}_{3}$ and $\mathrm{H}_{2} \mathrm{SO}_{4}$ lead to $\left[\mathrm{Au}\left(\mathrm{NO}_{3}\right)(\mathrm{NHC})\right]$ and $\left[(\mathrm{Au}(\mathrm{NHC}))_{2}\left(\mu^{2}-\mathrm{SO}_{4}\right)\right]$, respectively, ${ }^{128}$ while reactions with $\mathrm{HF}$ can yield fluoride or bifluoride complexes. ${ }^{129}$

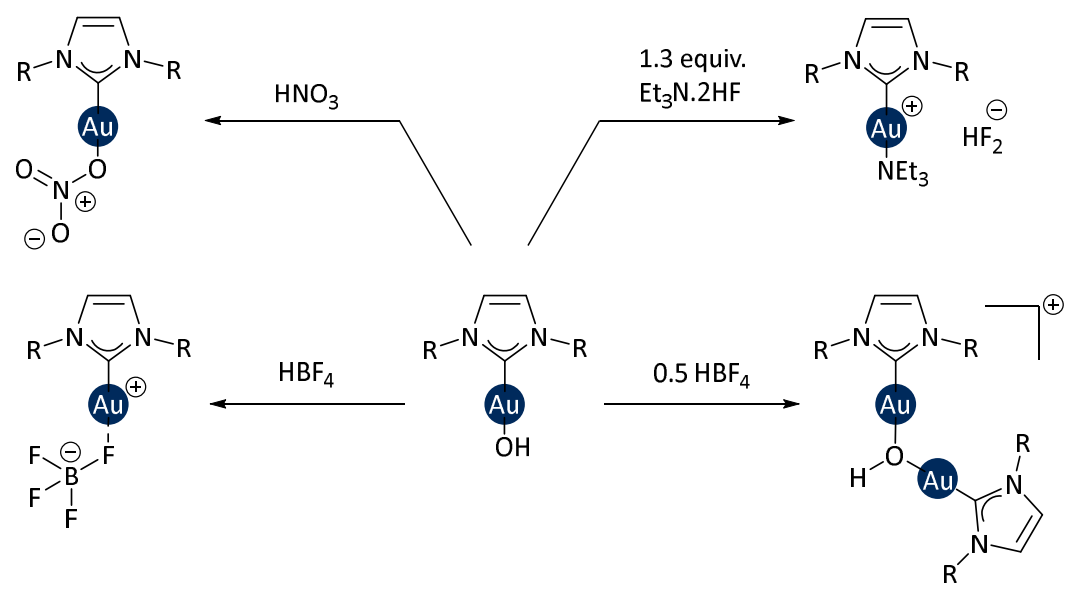

Scheme 37. Reactions of $[\mathrm{Au}(\mathrm{OH})(\mathrm{NHC})]$ with acids. ${ }^{122,125,128,129}$

These digold complexes can be used as precursors to other digold species that are useful in the development of our understanding about the role(s) of digold complexes in catalysis. They undergo reaction with terminal alkynes to form $\sigma, \pi$-digold acetylide complexes (themselves useful catalysts), ${ }^{130}$ and react with boronic acids to form gem-diaurated species (Scheme 38 ). ${ }^{131}$ Digold hydroxides have also found application in many different reactions, ${ }^{92}$ and most notably in hydrophenoxylation, hydroalkoxylation, and hydrocarboxylation reactions that are not readily catalysed by monomeric species. ${ }^{132-135}$ 


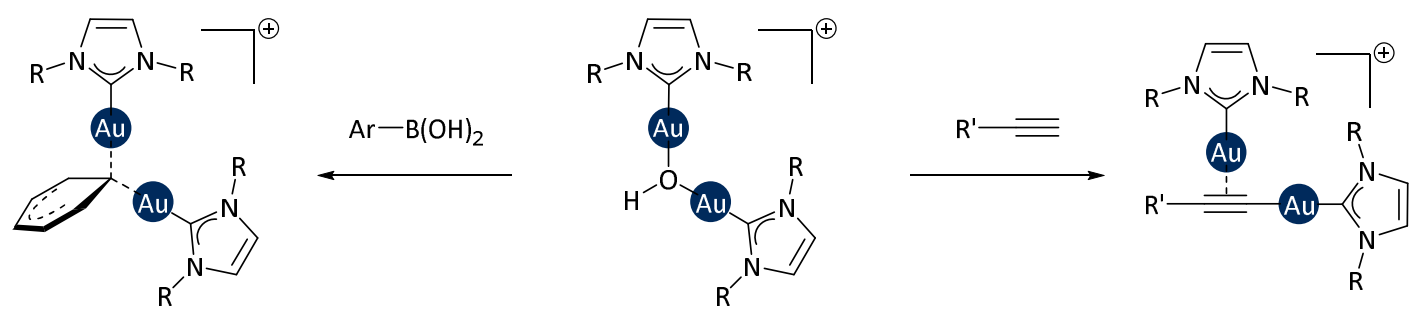

Scheme 38. Reactions of digold hydroxide complexes.

Phosphine-supported gold(I) hydroxide complexes are also known. [AuCl( $\left.\left.\mathrm{PPh}_{3}\right)\right]$ (and analogues) undergo halide abstraction in wet DCM to form $\left[\mathrm{Au}\left(\mathrm{OH}_{2}\right)\left(\mathrm{PAr}_{3}\right)\right]^{+}$, which tetramerise in the presence of molecular sieves to form a species with two bridging hydroxide ligands and several goldgold interactions. Further dehydration leads to $\left[\left(\mathrm{Au}\left(\mathrm{PPh}_{3}\right)\right)_{3}\left(\mu^{3}-\mathrm{O}\right)\right] \cdot{ }^{136}$ Related species supported by polyoxometalate units have also been reported. ${ }^{137}$ Buchwald-type ligands are often used in gold catalysis, and species such as $[\mathrm{Au}(\mathrm{OH})(\mathrm{JohnPhos})]$ and $\left[(\mathrm{Au}(\mathrm{JohnPhos}))_{2}(\mu-\mathrm{OH})\right]^{+}$have been prepared and characterised (JohnPhos $=2$-phenyl(ditertbutylphosphino)benzene). ${ }^{138}$ The latter was generated by the reaction of [Au(OTf)(JohnPhos)] with water in the presence of a proton sponge, and underwent reaction with $\mathrm{KOH}$ to form the corresponding monomeric hydroxide complex.

Several examples of gold hydroxide complexes supported by other ligand types have been discosed. A bis(2-pyridylimino)isoindole (BPI) gold(III) chloride complex has been prepared, and could be converted to the hydroxide complex simply by stirring in acetonitrile/water overnight. The hydroxide complex was shown to deprotonate methanol to form the corresponding methoxide, or transmetalate with $\mathrm{TMSN}_{3}$ to form a gold(III) azide species (Scheme 39). ${ }^{139}$

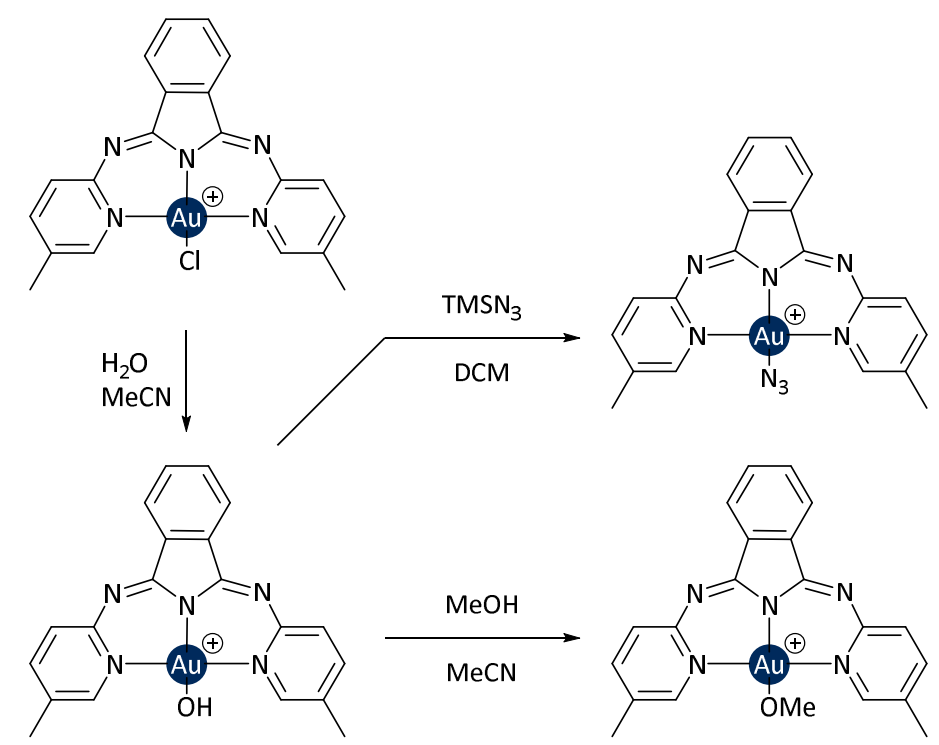

Scheme 39. Synthesis and reactions of a BPI gold(III) hydroxide complex. ${ }^{139}$ 
Bochman has studied the behaviour of a number of different gold complexes supported by 2,6-diarylpyridine ligands, including the corresponding gold(III) hydroxide (20). ${ }^{140}$ The hydroxide was prepared by reaction of the chloride or trifluoroacetate complex with $\mathrm{CsOH}$ or $\mathrm{KOH}$, respectively (Scheme 40 (a)). The hydroxide species exhibits a range of reactivity, including the deprotonation of alkynes, $\mathrm{N}$-heterocycles, and fluoroarenes, and transmetallation with boronic acids. Most notably, reduction with $\mathrm{LiBEt}_{3} \mathrm{H}$ leads to the formation of a gold(III) hydride complex (Scheme 40 (b); ${ }^{141}$ the hydride species (21) will react with the hydroxide to form a gold(II)-gold(II) dimer linked by a formal gold-gold bond (22).

(a)

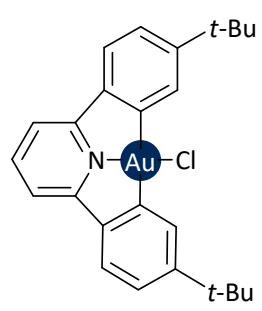

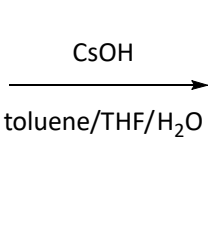

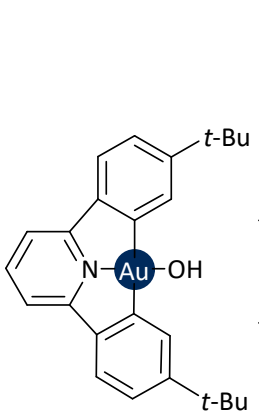

20
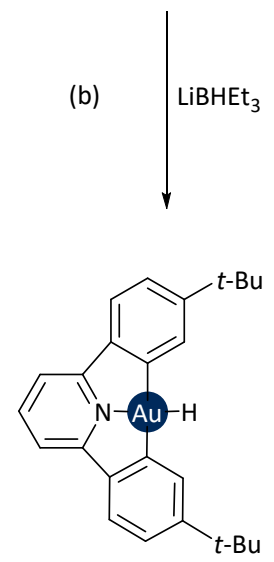

21
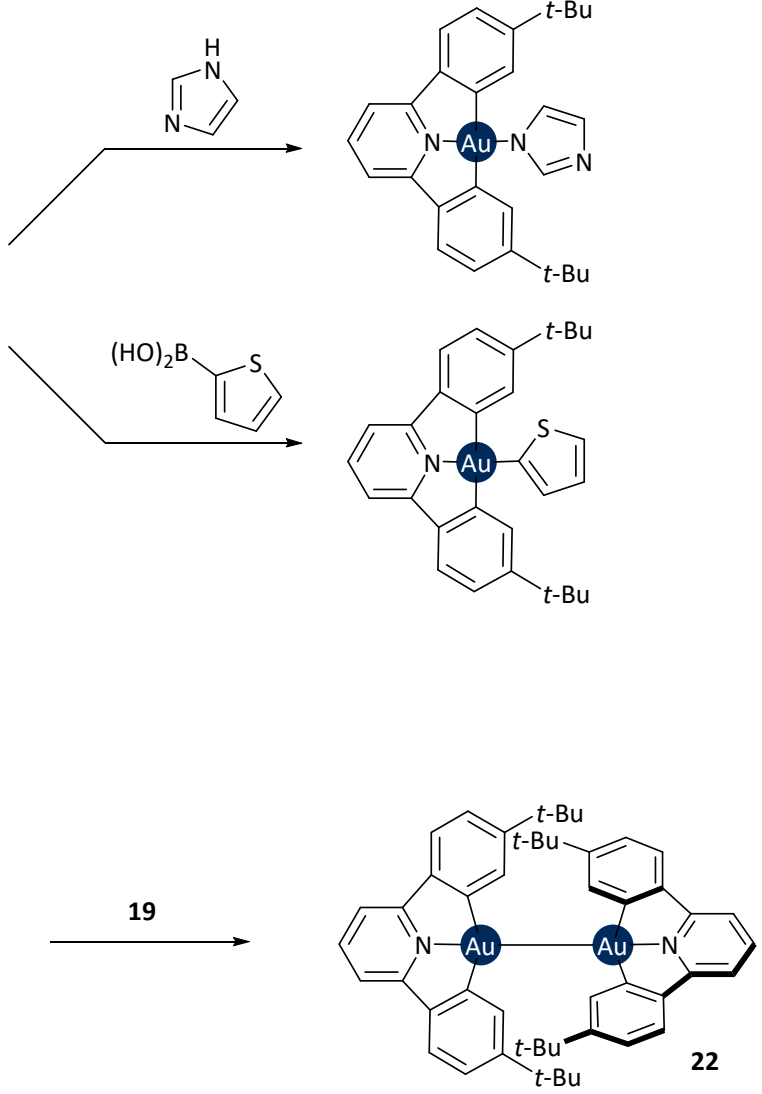

Scheme 40. (a) Synthesis and reactivity of a gold(III) hydroxide complex supported by a CNC ligand. ${ }^{140}$ (b) Synthesis and reactions of a related gold(III) hydride species.

Complex $\mathbf{2 0}$ undergoes reaction with peroxide reagents to yield a number of new complexes (Scheme 41 (a)). ${ }^{142}$ Reaction with tert-butyl peroxide leads to the corresponding gold(III) peroxide (23); reaction with hydrogen peroxide leads initially to a terminal hydroxide complex (24), which can be dehydrated to form a dimeric species (25). In addition, the hydroxide $\mathbf{2 0}$ can be dehydrated to form the oxo-bridged compound 26 (Scheme 41 (b)). 20 and 23-26 will all transfer an oxygen atom to $\mathrm{PAr}_{3}$ to form the corresponding phosphine oxide. 
(a)

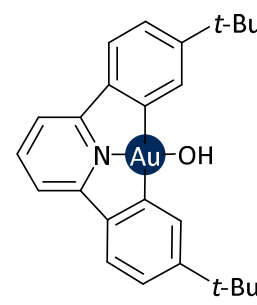

20

(b)

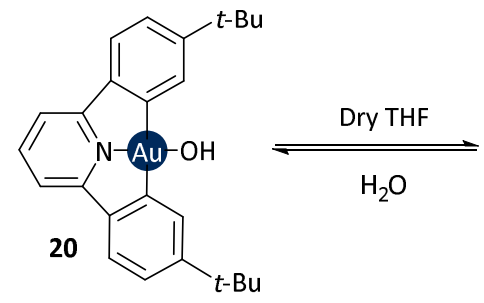

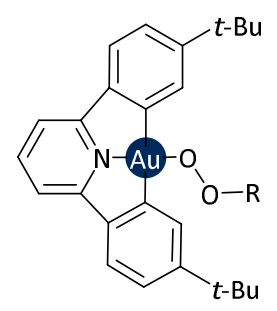

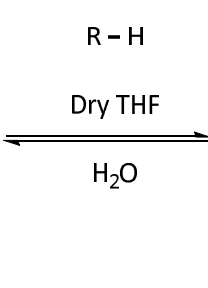

$23 \mathrm{R}-{ }^{t} \mathrm{Bu}$

$24 \mathrm{R}$ - H
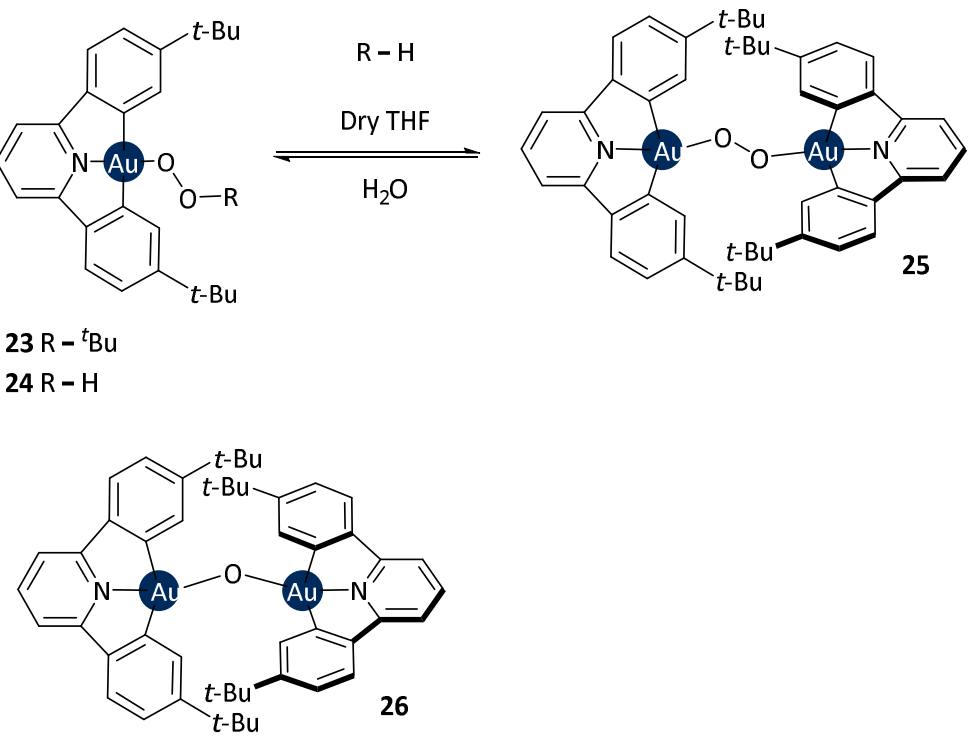

Scheme 41. (a) Reactivity of a gold(III) hydroxide with peroxide reagents. (b) Dehydration of a gold(III) hydroxide complex.

\section{Summary}

This review presents and discusses a range of complexes that all bear a hydroxide ligand, and provides insight into the range of reactivity that is available and how this can be harnessed in catalysis. While the most-studied examples of late transition metal hydroxide complexes in recent times are NHC-gold compounds, much of the reactivity is common across the late transition metals. Salt metathesis remains the most common synthetic route, and the hydroxide ligand thus installed is typically a robust and rather general - within the confines of $\mathrm{pK}_{\mathrm{a}}$ limitations - method by which other groups can be installed. Recent reports of $\mathrm{CO}_{2}$ insertion into hydroxide complexes and their derivatives further enhance the scope of reactivity, and the use of boronic acids and silanes for transmetalation reactions allows the organometallic chemist to deploy this vast range of known building blocks in the quest for new, exciting, and useful complexes of the late transition metals.

\section{Acknowledgements}

DJN thanks the University of Strathclyde for a Chancellor's Fellowship and SPN acknowledges support from the European Research Council (ERC Advanced Researcher Grant 227817-FUNCAT) 


\section{References}

1. L. M. Martínez-Prieto, C. Melero, D. del Río, P. Palma, J. Cámpora and E. Álvarez, Organometallics, 2012, 31, 1425-1438.

2. B. P. Carrow and J. F. Hartwig, J. Am. Chem. Soc., 2011, 133, 2116-2119.

3. A. H. Christian, P. Müller and S. Monfette, Organometallics, 2014, 33, 2134-2137.

4. I. I. F. Boogaerts and S. P. Nolan, J. Am. Chem. Soc., 2010, 132, 8858-8859.

5. C. P. Richers, J. A. Bertke and T. B. Rauchfuss, Dalton Trans., 2017, 46, 8756-8762.

6. H. W. Roesky, S. Singh, K. K. M. Yusuff, J. A. Maguire and N. S. Hosmane, Chem. Rev., 2006, 106, 3813-3843.

7. M. D. Walter and P. S. White, Dalton Trans., 2012, 41, 8506-8508.

8. O. A. Groß, S. Lauk, C. Müller, W. Gidt, Y. Sun, S. Demeshko, F. Meyer and H. Sitzmann, Eur. J. Inorg. Chem., 2017, 2017, 3635-3643.

9. Y.-C. Shi, W. Yang, Y. Shi and D.-C. Cheng, Journal of Coordination Chemistry, 2014, 67, 23302343.

10. A. J. Kendall, L. N. Zakharov and J. D. Gilbertson, Inorg. Chem., 2010, 49, 8656-8658.

11. R. Lopes, J. M. S. Cardoso, L. Postigo and B. Royo, Catalysis Letters, 2013, 143, 1061-1066.

12. C. S. Yi, T. N. Zeczycki and I. A. Guzei, Organometallics, 2006, 25, 1047-1051.

13. C. S. Yi and D. W. Lee, Organometallics, 2009, 28, 947-949.

14. S. Kiyota, H. Soeta, N. Komine, S. Komiya and M. Hirano, J. Mol. Cat. A., Chem., 2017, 426, 419428.

15. S. Kiyota, T. Kobori, H. Soeta, Y.-i. Ichikawa, N. Komine, S. Komiya and M. Hirano, Polyhedron, 2016, 120, 3-10.

16. R. Garcia-Alvarez, J. Francos, E. Tomas-Mendivil, P. Crochet and V. Cadierno, J. Organomet. Chem., 2014, 771, 93-104.

17. E. Alberico, A. J. J. Lennox, L. K. Vogt, H. Jiao, W. Baumann, H.-J. Drexler, M. Nielsen, A. Spannenberg, M. P. Checinski, H. Junge and M. Beller, J. Am. Chem. Soc., 2016, 138, 1489014904.

18. J.-P. Djukic, K. Parkhomenko, A. Hijazi, A. Chemmi, L. Allouche, L. Brelot, M. Pfeffer, L. Ricard and X.-F. Le Goff, Dalton Trans., 2009, DOI: 10.1039/B820426H, 2695-2711.

19. M. Martín, H. Horváth, E. Sola, Á. Kathó and F. Joó, Organometallics, 2009, 28, 561-566.

20. D. E. Prokopchuk, A. Collado, A. J. Lough and R. H. Morris, Dalton Trans., 2013, 42, 1021410220.

21. P. Nun, G. C. Fortman, A. M. Z. Slawin and S. P. Nolan, Organometallics, 2011, 30, 6347-6350.

22. J. Bosson and S. P. Nolan, J. Org. Chem., 2010, 75, 2039-2043.

23. A. Wu, A. Dehestani, E. Saganic, T. J. Crevier, W. Kaminsky, D. E. Cohen and J. M. Mayer, Inorg. Chim. Acta, 2006, 359, 2842-2849.

24. A. F. A. Peacock, A. Habtemariam, R. Fernández, V. Walland, F. P. A. Fabbiani, S. Parsons, R. E. Aird, D. I. Jodrell and P. J. Sadler, J. Am. Chem. Soc., 2006, 128, 1739-1748.

25. A. M. Kiefer, J. A. Giles and P. A. Shapley, Organometallics, 2007, 26, 1881-1887.

26. R. Castarlenas, M. A. Esteruelas and E. Oñate, Organometallics, 2008, 27, 3240-3247.

27. M. L. Buil, M. A. Esteruelas, J. Herrero, S. Izquierdo, I. M. Pastor and M. Yus, ACS Catal., 2013, 3, 2072-2075.

28. M. L. Buil, V. Cadierno, M. A. Esteruelas, J. Gimeno, J. Herrero, S. Izquierdo and E. Oñate, Organometallics, 2012, 31, 6861-6867.

29. M. L. Buil, J. J. F. Cardo, M. A. Esteruelas and E. Oñate, Organometallics, 2016, 35, 2171-2173.

30. J. C. Sarker, K. M. Uddin, M. S. Rahman, S. Ghosh, T. A. Siddiquee, D. A. Tocher, M. G. Richmond, G. Hogarth and S. E. Kabir, Inorg. Chim. Acta, 2014, 409, Part B, 320-329.

31. L.-C. Wu, T.-C. Weng, I. J. Hsu, Y.-H. Liu, G.-H. Lee, J.-F. Lee and Y. Wang, Inorg. Chem., 2013, 52, 11023-11033. 
32. R. Uson, L. A. Oro, J. A. Cabeza, H. E. Bryndza and M. P. Stepro, in Inorg. Synth., John Wiley \& Sons, Inc., 1985, DOI: 10.1002/9780470132548.ch25, pp. 126-130.

33. J. Yuwen, Y. Jiao, W. W. Brennessel and W. D. Jones, Inorg. Chem., 2016, 55, 9482-9491.

34. S. A. Burgess, T. Bolaño, T. B. Gunnoe, M. Sabat and W. H. Myers, Eur. J. Inorg. Chem., 2015, 2015, 1041-1052.

35. D. Inoki, T. Matsumoto, H. Hayashi, K. Takashita, H. Nakai and S. Ogo, Dalton Trans., 2012, 41, 4328-4334.

36. L. Palacios, M. J. Artigas, V. Polo, F. J. Lahoz, R. Castarlenas, J. J. Pérez-Torrente and L. A. Oro, ACS Catal., 2013, 3, 2910-2919.

37. B. J. Truscott, G. C. Fortman, A. M. Z. Slawin and S. P. Nolan, Org. Biomol. Chem., 2011, 9, 7038-7041.

38. B. J. Truscott, F. Nahra, A. M. Z. Slawin, D. B. Cordes and S. P. Nolan, Chem. Commun., 2014, DOI: 10.1039/C4CC07772E.

39. Y. Maeda, H. Hashimoto, I. Kinoshita and T. Nishioka, Inorg. Chem., 2015, 54, 448-459.

40. M. Sakate, A. Kashima, H. Hosoda, Y. Sunatsuki, H. Ota, A. Fuyuhiro and T. Suzuki, Inorg. Chim. Acta, 2016, 452, 205-213.

41. S. Bhagan, S. Sarkar and B. B. Wayland, Inorg. Chem., 2010, 49, 6734-6739.

42. B. J. Truscott, D. J. Nelson, C. Lujan, A. M. Z. Slawin and S. P. Nolan, Chem. Eur. J., 2013, 19, 7904-7916.

43. B. J. Truscott, D. J. Nelson, A. M. Z. Slawin and S. P. Nolan, Chem. Commun., 2014, 50, 286288.

44. B. J. Truscott, H. Kruger, P. B. Webb, M. Bühl and S. P. Nolan, Chem. Eur. J., 2015, 21, 69306935.

45. S. V. C. Vummaleti, G. Talarico, S. P. Nolan, L. Cavallo and A. Poater, Organic Chemistry Frontiers, 2016, 3, 19-23.

46. D. J. Nelson, J. A. Fernandez-Salas, B. J. Truscott and S. P. Nolan, Org. Biomol. Chem., 2014, 12, 6672-6676.

47. I. Mena, E. A. Jaseer, M. A. Casado, P. García-Orduña, F. J. Lahoz and L. A. Oro, Chem. Eur. J., 2013, 19, 5665-5675.

48. D. J. Nelson, B. J. Truscott, A. M. Z. Slawin and S. P. Nolan, Inorg. Chem., 2013, 52, 1267412681.

49. R. J. Burford, W. E. Piers, D. H. Ess and M. Parvez, J. Am. Chem. Soc., 2014, 136, 3256-3263.

50. L. E. Doyle, W. E. Piers, J. Borau-Garcia, M. J. Sgro and D. M. Spasyuk, Chem. Sci., 2016, 7, 921931.

51. M. Feller, E. Ben-Ari, Y. Diskin-Posner, R. Carmieli, L. Weiner and D. Milstein, J. Am. Chem. Soc., 2015, 137, 4634-4637.

52. B. R. Dible and M. S. Sigman, Inorg. Chem., 2006, 45, 8430-8441.

53. B. R. Dible, M. S. Sigman and A. M. Arif, Inorg. Chem., 2005, 44, 3774-3776.

54. B. R. Dible and M. S. Sigman, J. Am. Chem. Soc., 2003, 125, 872-873.

55. R. C. Poulten, I. López, A. Llobet, M. F. Mahon and M. K. Whittlesey, Inorg. Chem., 2014, DOI: 10.1021/ic500213h.

56. A. J. J. Lennox and G. C. Lloyd-Jones, Angew. Chem. Int. Ed., 2013, 52, 7362-7370.

57. T. J. Schmeier, A. Nova, N. Hazari and F. Maseras, Chem. Eur. J., 2012, 18, 6915-6927.

58. A. Collado, A. Gomez-Suarez, P. B. Webb, H. Kruger, M. Buhl, D. B. Cordes, A. M. Z. Slawin and S. P. Nolan, Chem. Commun., 2014, 50, 11321-11324.

59. W. Seals, H. Arman, S. B. H. Bach and G. T. Musie, Inorg. Chem. Commun., 2014, 44, 177-179.

60. I. Morales-Becerril, M. Flores-Álamo, A. Tlahuext-Aca, A. Arévalo and J. J. García, Organometallics, 2014, 33, 6796-6802.

61. S. Chakraborty, P. E. Piszel, C. E. Hayes, R. T. Baker and W. D. Jones, J. Am. Chem. Soc., 2015, 137, 14264-14267. 
62. J. Perez, J. L. Serrano, J. M. Galiana, F. L. Cumbrera, A. L. Ortiz, G. Sanchez and J. Garcia, Acta Crystallographica Section B, 2007, 63, 75-80.

63. J. L. Serrano, L. Garcia, J. Perez, E. Perez, J. M. Galiana, J. Garcia, M. Martinez, G. Sanchez and I. d. Silva, Dalton Trans., 2011, 40, 156-168.

64. J. L. Serrano, J. Pérez, L. García, G. Sánchez, J. García, P. Lozano, V. Zende and A. Kapdi, Organometallics, 2015, 34, 522-533.

65. M. D. Santana, R. García-Bueno, G. García, G. Sánchez, J. García, J. Pérez, L. García and J. L. Serrano, Inorg. Chim. Acta, 2011, 378, 49-55.

66. M. D. Santana, R. Garcia-Bueno, G. Garcia, G. Sanchez, J. Garcia, J. Perez, L. Garcia and J. L. Serrano, Dalton Trans., 2011, 40, 3537-3546.

67. W. D. Bailey, L. Luconi, A. Rossin, D. Yakhvarov, S. E. Flowers, W. Kaminsky, R. A. Kemp, G. Giambastiani and K. I. Goldberg, Organometallics, 2015, 34, 3998-4010.

68. J. D. Egbert, A. Chartoire, A. M. Z. Slawin and S. P. Nolan, Organometallics, 2011, 30, 44944496.

69. M. L. Scheuermann, D. W. Boyce, K. A. Grice, W. Kaminsky, S. Stoll, W. B. Tolman, O. Swang and K. I. Goldberg, Angew. Chem. Int. Ed., 2014, 53, 6492-6495.

70. A. V. Sberegaeva, P. Y. Zavalij and A. N. Vedernikov, J. Am. Chem. Soc., 2016, 138, 1446-1455.

71. F. Qu, J. R. Khusnutdinova, N. P. Rath and L. M. Mirica, Chem. Commun., 2014, 50, 3036-3039.

72. S. Takemoto and V. V. Grushin, J. Am. Chem. Soc., 2013, 135, 16837-16840.

73. A. A. Thomas and S. E. Denmark, Science, 2016, 352, 329-332.

74. A. A. Thomas, H. Wang, A. F. Zahrt and S. E. Denmark, J. Am. Chem. Soc., 2017, DOI: 10.1021/jacs.6b13384.

75. S. Ostrowska, J. Lorkowski, M. Kubicki and C. Pietraszuk, ChemCatChem, 2016, 8, 3580-3583.

76. B. Lippert and P. J. Sanz Miguel, Coord. Chem. Rev., 2016, 327, 333-348.

77. T. L. Lohr, W. E. Piers and M. Parvez, Inorg. Chem., 2012, 51, 4900-4902.

78. A. R. Petersen, A. J. P. White and G. J. P. Britovsek, Dalton Trans., 2016, 45, 14520-14523.

79. N. A. Smythe, K. A. Grice, B. S. Williams and K. I. Goldberg, Organometallics, 2009, 28, 277288.

80. G. C. Fortman, A. M. Z. Slawin and S. P. Nolan, Organometallics, 2010, 29, 3966-3972.

81. S. Gaillard, C. S. J. Cazin and S. P. Nolan, Acc. Chem. Res., 2012, 45, 778-787.

82. N. P. Mankad, D. S. Laitar and J. P. Sadighi, Organometallics, 2004, 23, 3369-3371.

83. A. Petronilho, H. Muller-Bunz and M. Albrecht, Chem. Commun., 2012, 48, 6499-6501.

84. I. I. F. Boogaerts, G. C. Fortman, M. R. L. Furst, C. S. J. Cazin and S. P. Nolan, Angew. Chem. Int. Ed., 2010, 49, 8674-8677.

85. L. Zhang, J. Cheng, T. Ohishi and Z. Hou, Angew. Chem. Int. Ed., 2010, 49, 8670-8673.

86. H. Batebi, F. Zarkoob, K. Daraei, B. F. Yates and A. Ariafard, J. Organomet. Chem., 2013, 748, 89-97.

87. M. Lesieur, F. Lazreg and C. S. J. Cazin, Chem. Commun., 2014, 50, 8927-8929.

88. N. O. Thiel and J. F. Teichert, Org. Biomol. Chem., 2016, 14, 10660-10666.

89. N. O. Thiel, S. Kemper and J. F. Teichert, Tetrahedron, 2017, 73, 5023-5028.

90. E. Korytiakova, N. O. Thiel, F. Pape and J. F. Teichert, Chem. Commun., 2017, DOI: 10.1039/C6CC09067B.

91. F. Lazreg, S. Guidone, A. Gomez-Herrera, F. Nahra and C. S. J. Cazin, Dalton Trans., 2017, 46, 2439-2444.

92. Y. Oonishi, A. Gómez-Suárez, A. R. Martin and S. P. Nolan, Angew. Chem. Int. Ed., 2013, 52, 9767-9771.

93. R. Molteni, K. Edkins, M. Haehnel and A. Steffen, Organometallics, 2016, 35, 629-640.

94. R. Marion, F. Sguerra, F. Di Meo, E. Sauvageot, J.-F. Lohier, R. Daniellou, J.-L. Renaud, M. Linares, M. Hamel and S. Gaillard, Inorg. Chem., 2014, 53, 9181-9191.

95. F. Lazreg, A. M. Z. Slawin and C. S. J. Cazin, Organometallics, 2012, 31, 7969-7975.

96. F. Lazreg, D. B. Cordes, A. M. Z. Slawin and C. S. J. Cazin, Organometallics, 2015, 34, 419-425. 
97. M. Trose, F. Lazreg, T. Chang, F. Nahra, D. B. Cordes, A. M. Z. Slawin and C. S. J. Cazin, ACS Catal., 2017, 7, 238-242.

98. H. Farrokhpour, H. Hadadzadeh, F. Darabi, F. Abyar, H. A. Rudbari and T. Ahmadi-Bagheri, RSC Advances, 2014, 4, 35390-35404.

99. S. Jamali, S. Abedanzadeh, N. K. Khaledi, H. Samouei, Z. Hendi, S. Zacchini, R. Kia and H. R. Shahsavari, Dalton Trans., 2016, 45, 17644-17651.

100. Q.-X. Liu, A.-H. Chen, X.-J. Zhao, Y. Zang, X.-M. Wu, X.-G. Wang and J.-H. Guo, CrystEngComm, 2011, 13, 293-305.

101. S. Gaillard, A. M. Z. Slawin and S. P. Nolan, Chem. Commun., 2010, 46, 2742-2744.

102. S. R. Patrick, A. Gómez-Suárez, A. M. Z. Slawin and S. P. Nolan, Organometallics, 2013, 33, 421424.

103. S. R. Patrick, A. Collado, S. Meiries, A. M. Z. Slawin and S. P. Nolan, J. Organomet. Chem., 2015, 775, 152-154.

104. A. Gomez-Suarez, R. S. Ramon, A. M. Z. Slawin and S. P. Nolan, Dalton Trans., 2012, 41, 54615463.

105. F. Nahra, S. R. Patrick, A. Collado and S. P. Nolan, Polyhedron, 2014, 84, 59-62.

106. R. M. P. Veenboer, D. Gasperini, F. Nahra, D. B. Cordes, A. M. Z. Slawin, C. S. J. Cazin and S. P. Nolan, Organometallics, 2017, DOI: 10.1021/acs.organomet.7b00622.

107. A. Collado, A. Gomez-Suarez, Y. Oonishi, A. M. Z. Slawin and S. P. Nolan, Chem. Commun., 2013, 49, 10745-10747.

108. D.-A. Roşca, J. Fernandez-Cestau, D. L. Hughes and M. Bochmann, Organometallics, 2015, 34, 2098-2101.

109. J. Weaver, S. Gaillard, C. Toye, S. Macpherson, S. P. Nolan and A. Riches, Chem. Eur. J., 2011, 17, 6620-6624.

110. P. Nun, S. Gaillard, A. M. Z. Slawin and S. P. Nolan, Chem. Commun., 2010, 46, 9113-9115.

111. S. Gaillard, P. Nun, A. M. Z. Slawin and S. P. Nolan, Organometallics, 2010, 29, 5402-5408.

112. G. C. Fortman, A. Poater, J. W. Levell, S. Gaillard, A. M. Z. Slawin, I. D. W. Samuel, L. Cavallo and S. P. Nolan, Dalton Trans., 2010, 39, 10382-10390.

113. J. D. Egbert, A. M. Z. Slawin and S. P. Nolan, Organometallics, 2013, 32, 2271-2274.

114. A. Gómez-Suárez, D. J. Nelson, D. G. Thompson, D. B. Cordes, D. Graham, A. M. Z. Slawin and S. P. Nolan, Beilstein J. Org. Chem., 2013, 9, 2216-2223.

115. D. Gasperini, A. Collado, A. Goméz-Suárez, D. B. Cordes, A. M. Z. Slawin and S. P. Nolan, Chem. Eur. J., 2015, 21, 5403-5412.

116. S. Dupuy, L. Crawford, M. Bühl, A. M. Z. Slawin and S. P. Nolan, Adv. Synth. Catal., 2012, 354, 2380-2386.

117. S. Dupuy, A. M. Z. Slawin and S. P. Nolan, Chem. Eur. J., 2012, 18, 14923-14928.

118. L. Falivene, D. J. Nelson, S. Dupuy, S. P. Nolan, A. Poater and L. Cavallo, ChemistryOpen, 2016, 5, 60-64.

119. L. Jin, D. S. Weinberger, M. Melaimi, C. E. Moore, A. L. Rheingold and G. Bertrand, Angew. Chem. Int. Ed., 2014, 53, 9059-9063.

120. S. Dupuy, F. Lazreg, A. M. Z. Slawin, C. S. J. Cazin and S. P. Nolan, Chem. Commun., 2011, 47, 5455-5457.

121. S. Dupuy, L. Crawford, M. Bühl and S. P. Nolan, Chem. Eur. J., 2015, 21, 3399-3408.

122. S. Gaillard, J. Bosson, R. S. Ramón, P. Nun, A. M. Z. Slawin and S. P. Nolan, Chem. Eur. J., 2010, 16, 13729-13740.

123. P. Nun, R. S. Ramón, S. Gaillard and S. P. Nolan, J. Organomet. Chem., 2011, 696, 7-11.

124. P. Nun, J. D. Egbert, M.-J. Oliva-Madrid and S. P. Nolan, Chem. Eur. J., 2012, 18, 1064-1067.

125. R. S. Ramón, S. Gaillard, A. Poater, L. Cavallo, A. M. Z. Slawin and S. P. Nolan, Chem. Eur. J., 2011, 17, 1238-1246.

126. A. Gómez-Suárez and S. P. Nolan, Angew. Chem. Int. Ed., 2012, 51, 8156-8159.

127. A. S. K. Hashmi, Acc. Chem. Res., 2014, 47, 864-876. 
128. M. Brill, F. Nahra, A. Gómez-Herrera, C. Zinser, D. B. Cordes, A. M. Z. Slawin and S. P. Nolan, ChemCatChem, 2017, 9, 117-120.

129. F. Nahra, S. R. Patrick, D. Bello, M. Brill, A. Obled, D. B. Cordes, A. M. Z. Slawin, D. O'Hagan and S. P. Nolan, ChemCatChem, 2015, 7, 240-244.

130. A. S. K. Hashmi, T. Lauterbach, P. Nösel, M. H. Vilhelmsen, M. Rudolph and F. Rominger, Chem. Eur. J., 2013, 19, 1058-1065.

131. A. Gómez-Suárez, S. Dupuy, A. M. Z. Slawin and S. P. Nolan, Angew. Chem. Int. Ed., 2013, 52, 938-942.

132. A. Gómez-Suárez, Y. Oonishi, S. Meiries and S. P. Nolan, Organometallics, 2013, 32, 1106-1111.

133. A. Gómez-Suárez, Y. Oonishi, A. R. Martin, S. V. C. Vummaleti, D. J. Nelson, D. B. Cordes, A. M. Z. Slawin, L. Cavallo, S. P. Nolan and A. Poater, Chem. Eur. J., 2016, 22, 1125-1132.

134. R. M. P. Veenboer, S. Dupuy and S. P. Nolan, ACS Catal., 2015, 5, 1330-1334.

135. S. Dupuy, D. Gasperini and S. P. Nolan, ACS Catal., 2015, 5, 6918-6921.

136. Y. Tang and B. Yu, RSC Advances, 2012, 2, 12686-12689.

137. T. Yoshida, S. Matsunaga and K. Nomiya, Dalton Trans., 2013, 42, 11418-11425.

138. A. Zhdanko, M. Ströbele and M. E. Maier, Chem. Eur. J., 2012, 18, 14732-14744.

139. T. Roth, H. Wadepohl and L. H. Gade, Eur. J. Inorg. Chem., 2016, 2016, 1184-1191.

140. D.-A. Rosca, D. A. Smith and M. Bochmann, Chem. Commun., 2012, 48, 7247-7249.

141. D.-A. Roşca, D. A. Smith, D. L. Hughes and M. Bochmann, Angew. Chem. Int. Ed., 2012, 51, 10643-10646.

142. D.-A. Roşca, J. A. Wright, D. L. Hughes and M. Bochmann, 2013, 4, 2167. 